
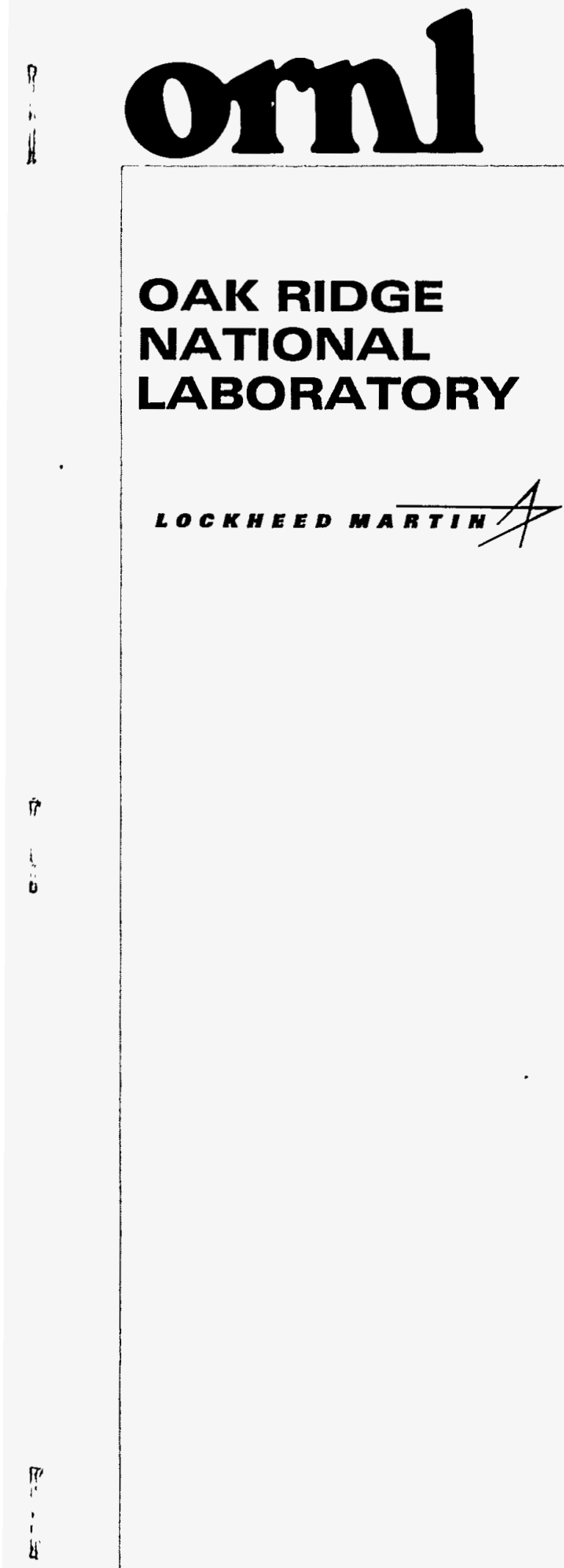

OAK RIDGE NATIONAL LABORATORY

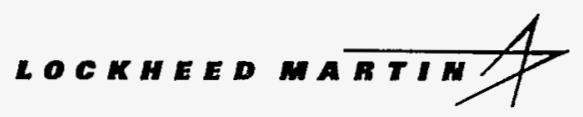

MANAGED AND OPERATED BY LOCKHEED MARTIN ENERGY RESEARCH CORPORATION FOR THE UNTEO STATES DEPARTMENT OF ENERGY

ORNL-27 (3-90)

\section{RECEIVED \\ JuI 224998 \\ OSTI}

PROGRESS REPORT AND TECHNOLOGY STATUS DEVELOPMENT OF AN EG\&G BERTHOLD LB-150 ALPHA/BETA PARTICULATE MONITOR FOR USE ON THE EAST TENNESSEE TECHNOLOGY PARK TOXIC SUBSTANCES CONTROL ACT INCINERATOR

Joel T. Shor and Suman P. N. Singh

Chemical Technology Division

Oak Ridge National Laboratory*

Oak Ridge, Tennessee 37831-6180

Luther V. Gibson, Jr.

ASO Customer Services Division East Tennessee Technology Park ${ }^{* *}$

Oak Ridge, Tennessee 37831-7274

June 1998 
This report has been reproduced directly from the best available copy.

Available to DOE and DOE contractors from the Office of Scientific and Technical Information, P.O. Box 62. Oak Ridge. TN 37831; prices available from (615) 576-8401, FTS 626-8401.

Available to the public from the National Technical Information Service, U.S. Department of Commerce, 5285 Port Royal Rd., Springfield, VA 22161.

This report was prepared as an account of work sponsored by an agency of the United States Govemment. Neither the United States Government nor any agency thereof, nor any of their employees, makes any warranty, express or implied, or assumes any legal liability or responsibility for the accuracy, completeness, or usefulness of any information, apparatus, product, or process disclosed, or represents that its use would not infringe privately owned rights. Reference herein to any specific commercial product, process, or service by trade name, trademark, manufecturer, or otherwise, does not necessarily constitute or imply its endorsement, recommendation, or favoring by the United States Govermment or any agency thereof. The views and opinions of authors expressed herein do not necessarily state or reflect those of the United States Government or any agency thereof. 


\section{DISCLAIMER}

Portions of this document may be illegible electronic image products. Images are produced from the best available original document. 


\title{
PROGRESS REPORT AND TECHNOLOGY STATUS DEVELOPMENT OF AN EG\&G BERTHOLD LB-150 ALPHA/BETA PARTICULATE MONITOR FOR USE ON THE EAST TENNESSEE TECHNOLOGY PARK TOXIC SUBSTANCES CONTROL ACT INCINERATOR
}

\author{
Joel T. Shor and Suman P. N. Singh \\ Chemical Technology Division \\ Oak Ridge National Laboratory* \\ Oak Ridge, Tennessee 37831-6180 \\ Luther V. Gibson, Jr. \\ ASO Customer Services Division \\ East Tennessee Technology Park** \\ Oak Ridge, Tennessee 37831-7274
}

June 1998

\section{MASTER}

\footnotetext{
*Managed by Lockheed Martin Energy Research Corp., under contract DE-AC05-96OR22464 for the U.S. Department of Energy.

**Managed by Lockheed Martin Energy Systems, Inc., under contract DE-AC05-840R21400 for the U.S. Department of Energy.
} 


\section{CONTENTS}

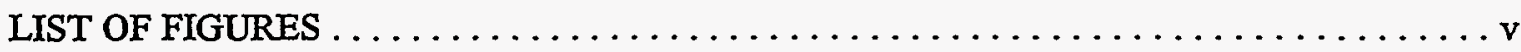

ABSTRACT $\ldots \ldots \ldots \ldots \ldots \ldots \ldots \ldots \ldots \ldots \ldots \ldots \ldots \ldots \ldots \ldots \ldots \ldots \ldots \ldots \ldots \ldots \ldots$

1. BACKGROUND AND GENERAL DESIGN CONSIDERATIONS $\ldots \ldots \ldots \ldots \ldots \ldots \ldots 1$

1.1 OTHER MONITORING EXPERIENCE $\ldots \ldots \ldots \ldots \ldots \ldots \ldots \ldots \ldots \ldots$

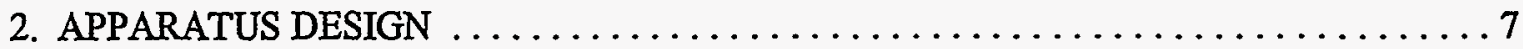

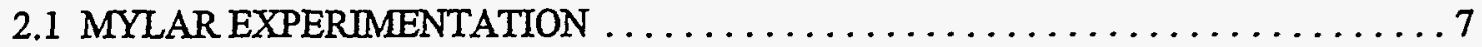

2.2 HUMIDIFICATION APPARATUS $\ldots \ldots \ldots \ldots \ldots \ldots \ldots \ldots \ldots \ldots \ldots \ldots$

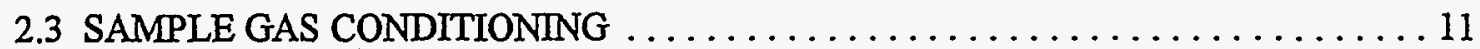

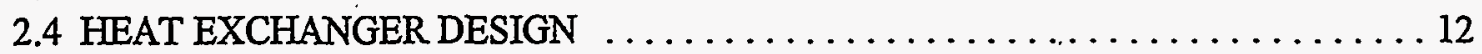

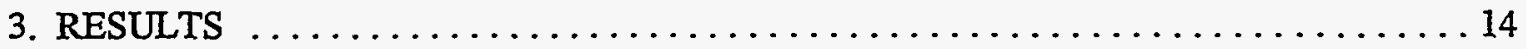

3.1 INITIAL STEAM CART TESTING $\ldots \ldots \ldots \ldots \ldots \ldots \ldots \ldots \ldots \ldots \ldots \ldots \ldots \ldots$

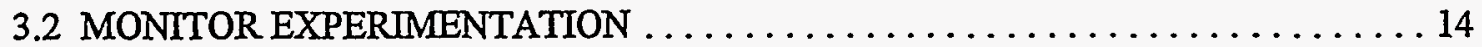

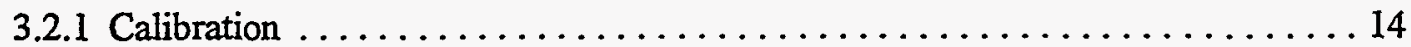

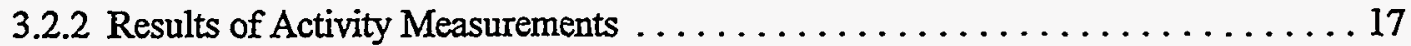

3.3 STATISTICS OF COUNTING . . . . . . . . . . . . . . . . . . . 19

3.4 STEAM AND ELEVATED TEMPERATURE EXPERIMENTATION . . . . . . . 25

3.5 DISCUSSION OF RADIONUCLIDE SENSITIVITY LOSS . . . . . . . . . . 31

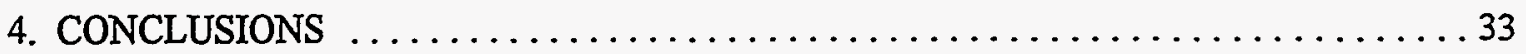

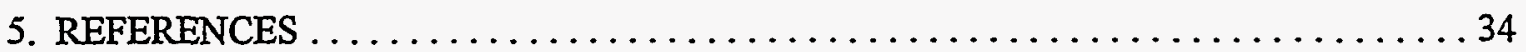

APPENDIX A. SAMPLE HUMIDIFICATION CALCULATIONS FOR AIR IN AT $78^{\circ} \mathrm{F}$, SATURATED WATER OUT AT $190^{\circ} \mathrm{F}$,

SATURATED AIR OUT AT $190^{\circ} \mathrm{F} \ldots \ldots \ldots \ldots \ldots \ldots \ldots \ldots \ldots$ A-1

APPENDIX B. HEAT-EXCHANGER DESIGN CALCULATIONS $\ldots \ldots \ldots \ldots \ldots \ldots$ B-1

APPENDIX C. PLATEAU VOLTAGE DATA $\ldots \ldots \ldots \ldots \ldots \ldots \ldots \ldots \ldots \ldots \ldots \ldots \ldots$

APPENDIX D. PSEUDOCOINCDENCE DATA $\ldots \ldots \ldots \ldots \ldots \ldots \ldots \ldots \ldots \ldots \ldots \ldots$ 


\section{•}




\section{LIST OF FIGURES}

1 Schematic of experimental apparatus to test the EG\&G-Berthold radionuclides

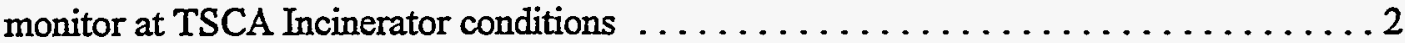

2 Schematic of EG\&G-Berthold radionuclides monitor on TSCA Incinerator stack ...... 3

3 Schematic of humidification-apparatus mass balance $\ldots \ldots \ldots \ldots \ldots \ldots \ldots$

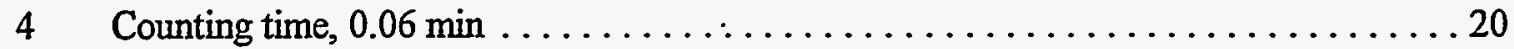

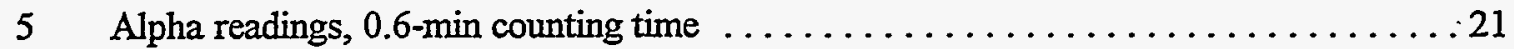

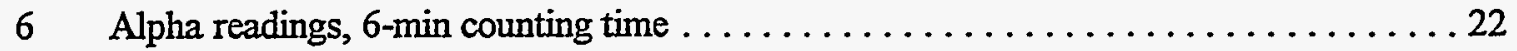

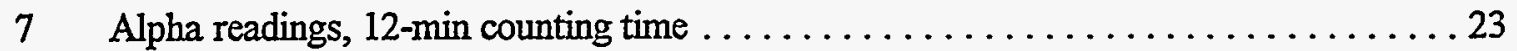

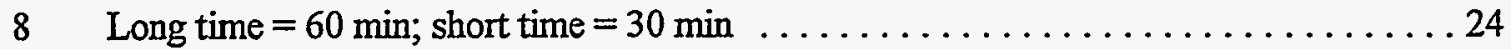

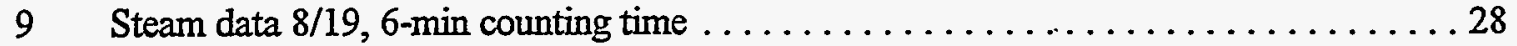

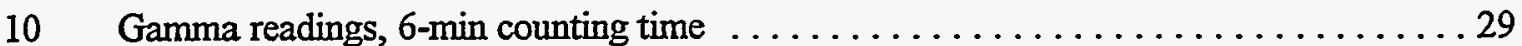

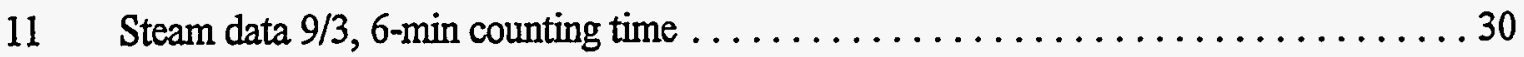

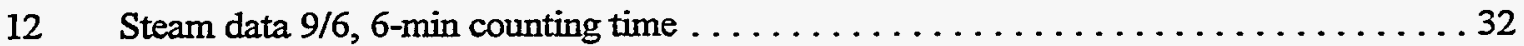

C.1 Beta plateau voltages $\ldots \ldots \ldots \ldots \ldots \ldots \ldots \ldots \ldots \ldots \ldots \ldots \ldots \ldots \ldots \ldots \ldots$

C.2 Alpha plateau voltages $\ldots \ldots \ldots \ldots \ldots \ldots \ldots \ldots \ldots \ldots \ldots \ldots \ldots \ldots \ldots \ldots$

D.1 Counts per second vs time in hours $\ldots \ldots \ldots \ldots \ldots \ldots \ldots \ldots \ldots \ldots \ldots \ldots \ldots \ldots \ldots$ 


\begin{abstract}
The purpose of this project was to modify and evaluate a commercially available EG\&G Berthold LB-150 alpha-beta radionuclide particulate monitor for the high-temperature and moisture-saturation conditions of the East Tennessee Technology Park (formerly K-25 Site) Toxic Substances Control Act (TSCA) Incinerator stack. The monitor was originally outfitted for operation at gas temperatures of $150^{\circ} \mathrm{F}$ on the defunct Los Alamos National Laboratory (LANL) controlled air incinerator, and the objective was to widen its operating envelope. A laboratory apparatus was constructed that simulated the effects of water-saturated air at the TSCA Incinerator stack-gas temperatures, $\sim 183^{\circ} \mathrm{F}$. An instrumented set of heat exchangers was constructed to then condition the gas so that the radionuclide monitor could be operated without condensation. Data were collected under the conditions of the elevated temperatures and humidities and are reported herein, and design considerations of the apparatus are provided. The heat exchangers and humidification equipment performed as designed, the Mylar film held, and the instrument suffered no ill effects. However, for reasons as yet undetermined, the sensitivity of the radionuclide detection diminishes as the gas temperature is elevated, whether the gas is humidified or not. The manufacturer has had no experience with (a) the operation of the monitor under these conditions and (b) any commercial market that might exist for an instrument that operates under these conditions. The monitor was not installed into the radiologically contaminated environment of the TSCA Incinerator stack pending resolution of this technical issue.
\end{abstract}




\section{BACKGROUND AND GENERAL DESIGN CONSIDERATIONS}

The purpose of this project is the testing of alpha-beta radionuclide particulate detectors under simulated and actual hazardous or radioactive waste incineration conditions. This report describes the construction of a laboratory apparatus to provide a simulated incinerator flue gas, modifications to the existing instrument, and the results of laboratory experimentation with the modified instrument.

The unit to be tested consisted of a stacked, pancake arrangement of alpha, beta, and gamma gas proportional detectors. The general arrangement of the monitor and the test apparatus is shown in Fig. 1. The proposed arrangement by which the detector is attached to the Toxic Substances Control Act (TSCA) Incinerator stack is shown in Fig. 2.

A test plan for the development and demonstration of the monitor outlined six general project tasks:

1. Laboratory calibration of the radionuclide monitor at ambient and elevated temperatures.

2. Construction of a steam generator and laboratory testing of the monitor on steam-air mixtures.

3. Laboratory testing of the modified monitor at simulated TSCA Incinerator operating conditions.

4. Long-term laboratory evaluation of the modified monitor at simulated TSCA Incinerator stack gas conditions.

5. Installation of monitor on TSCA Incinerator stack.

6. Continuous emission monitoring of TSCA Incinerator stack gases.

The apparatus must permit no condensation of moisture whatever until the sample gas has exited the filter on which the particulates are collected for radioactivity monitoring. There are two reasons for this constraint: (1) water can blind or block the filter, which is $99.95 \%$ efficient at $0.3-$ $\mu \mathrm{m}$ particulate size [per the di-octyl phthalate (DOP) smoke particle (i.e., DOP test)], and result in a high-pressure drop and low-sample flow, and (2) even the slightest condensation of water on the Mylar ${ }^{\mathrm{TM}}$ window of the detector will lead to a total loss in alpha sensitivity owing to the high absorbency of alpha radiation by water. Reference to the schematic of the device design, as shown in Fig. 1, will make clear the position of the detectors relative to the sample gas 
ORNL DWG 97C-382R

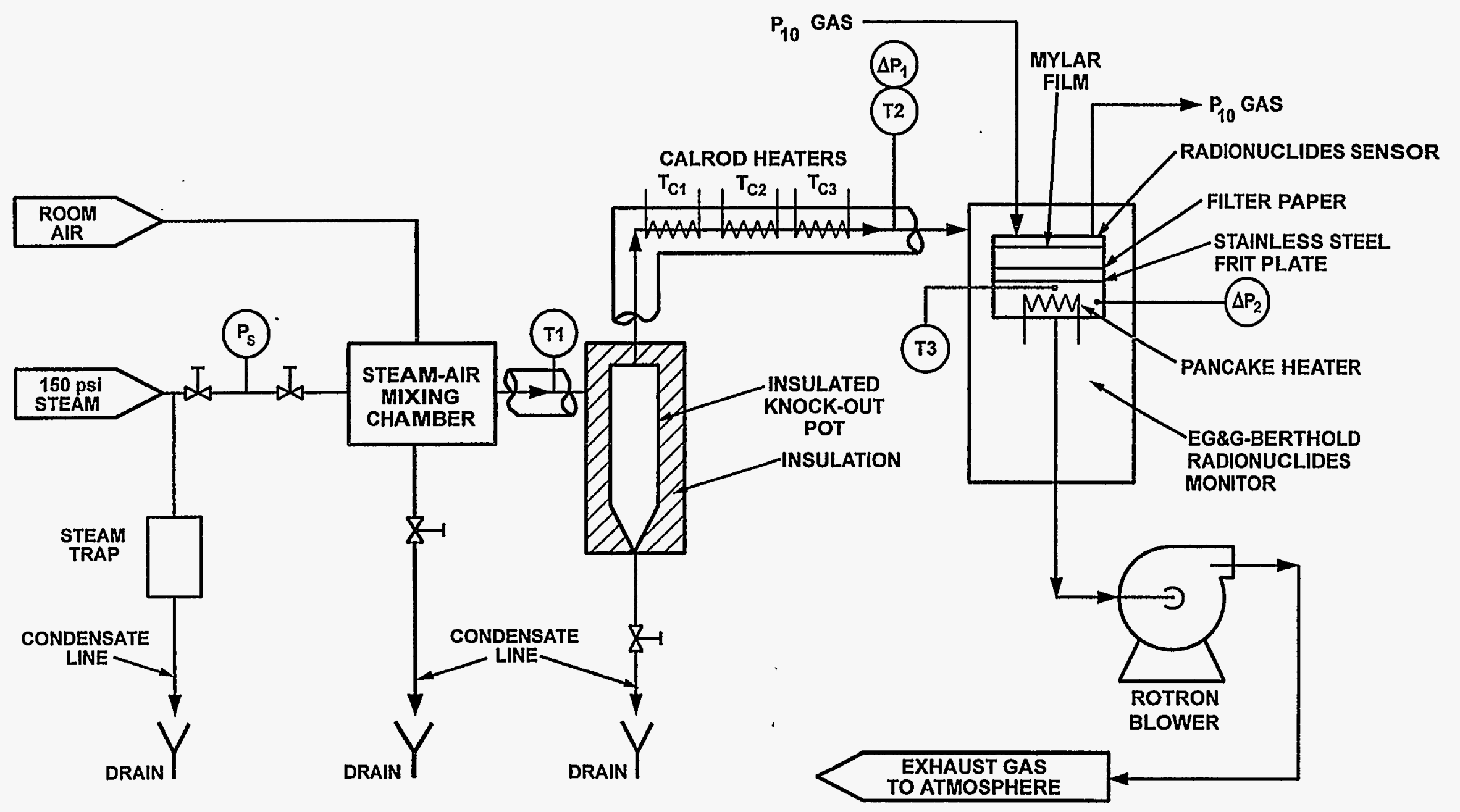

Fig. 1. Schematic of experimental apparatus to test the EG\&G-Berthold radionuclides monitor at TSCA Incinerator conditions. 


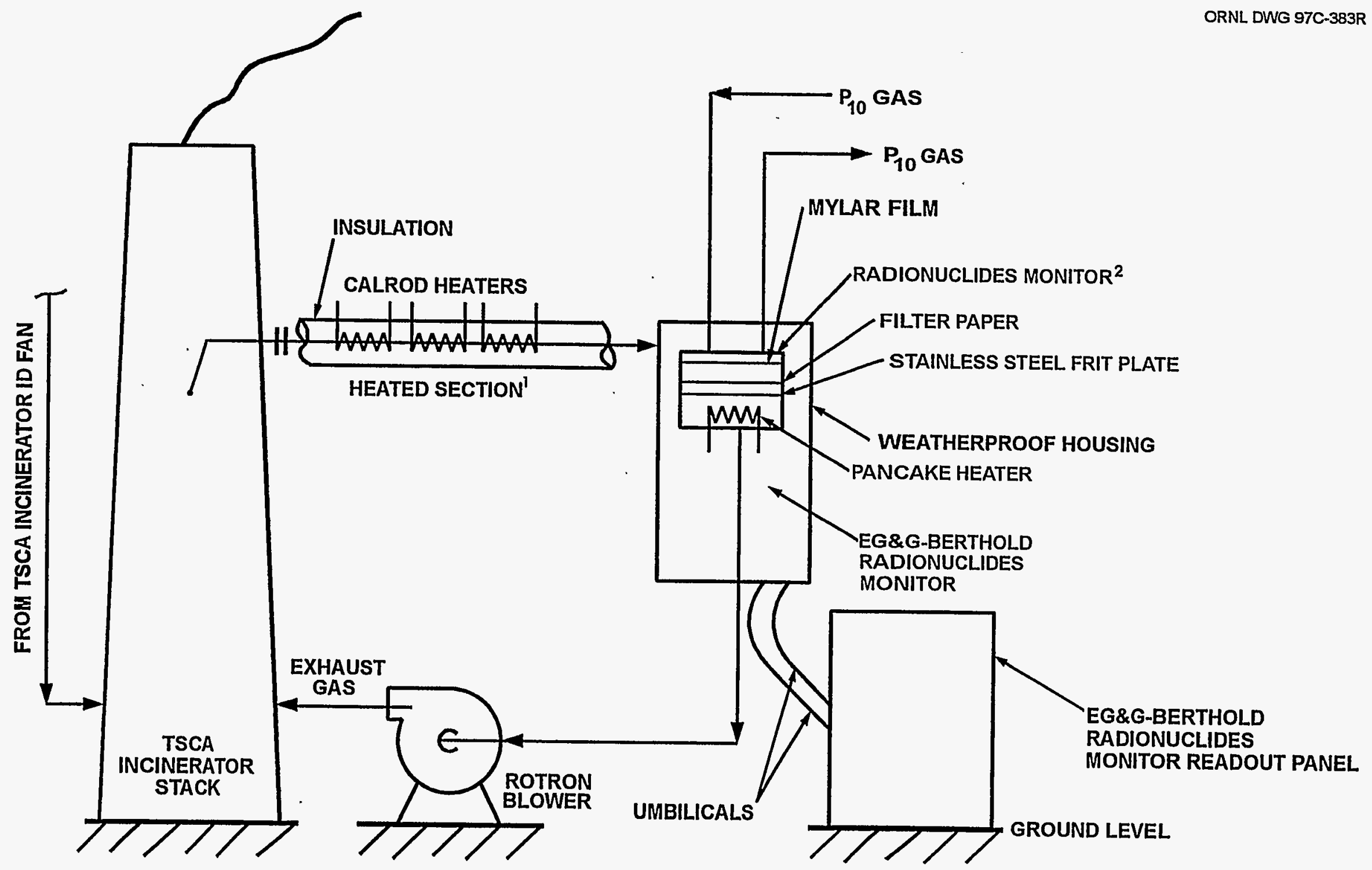

\footnotetext{
${ }^{1}$ TO PRECLUDE MOISTURE CONDENSATION BEFORE MONITORING
}

2 LOCATED ON SECOND LEVEL OF TSCA INCINERATOR STACK

Fig.2. Schematic of EG\&G-Berthold radionuclides monitor on TSCA Incinerator stack, 
flow and better illustrate these concerns. The detector element is flushed with a separate gas, $\mathrm{P}_{10}$, which is a mixture of argon and methane.

The effects of temperature on the Mylar window are a basic limitation to the highest temperature to which the gas may be raised. We chose $220^{\circ} \mathrm{F}$ as the operating temperature in order to place ourselves safely above the $183^{\circ} \mathrm{F}$ dew point (adiabatic saturation temperature) of the TSCA Incinerator stack gas. The stack gas temperature varies slightly from summer to winter, but usually the dew point of the gas stays below this figure.

Other parts of the apparatus must be designed to avoid excessive buildup of water or condensation in points downstream of the filter. At these points, some moisture can be tolerated; however, the regenerative centrifugal blowers with which the apparatus is equipped are limited to small amounts of water. We wish, however, to avoid filling the exhaust ducts with water-in which case an excessive pressure drop would be incurred, and the blowers might then become damaged.

The flow of gas to the monitor from the stack must avoid piping bends or a sharp angle in order to prevent the deposition of particulates. Similarly, to produce an honest representative sample, the length of the sample line from the stack to the monitor should be kept to a minimum. For these reasons, we planned to locate the monitor on the TSCA Incinerator stack with a minimum of auxiliary equipment attached to it. The monitor would be tested in the laboratory before attaching it to the stack to verify the design and to address unanticipated problems. At every juncture, the monitor had to be treated with delicacy because a rupture of the Mylar film could lead to a destruction of one of the detectors, each of which costs $\sim \$ 5000$.

The ultimate sensitivity of the detector that EG\&G advertises as $3.5 \mathrm{E}-12 \mu \mathrm{Ci} / \mathrm{mL}$ (sample collection for 1 hour at a background of $10 \mathrm{~Bq} / \mathrm{m}^{3}$ ) is very close to some 1996 data from the TSCA Incinerator stack $(1.6 \mathrm{E}-11 \mu \mathrm{Ci} / \mathrm{mL})$. Recent data from the National Emission Standards for Hazardous Air Pollutants (NESHAP) probe indicate that (a) uranium, thorium, and protactinium constitute the major radionuclide stack discharges in terms of curies and (b) that ${ }^{238} \mathrm{U}$ is the greatest source of exposure in millirems to the maximum exposed individual from the TSCA Incinerator. Table 1 lists radionuclide emissions from the incinerator for the year 1996. A compromise must be struck between the monitoring time and the desired or required sensitivity. The relative standard deviation varies inversely as the square root of the number of counts, as in Eq. (1). 


$$
\sigma_{\text {relative }}=\frac{1}{\sqrt{n}} \text {, }
$$

where $\sigma_{\text {relative }}$ is the relative standard deviation and $n$ is the number of counts also expressed as $n=R t$, where $R$ is the counting rate and $t$ is the counting period. As the monitoring time intervals are shortened, the number of counts decrease, and the sensitivity above background decreases. A further difficulty is that background radon concentration can vary by a factor of 1000 from day to night and is in the range of the waste radionuclide emissions from the TSCA Incinerator. Waste emissions are defined as nonradon emissions. The EG\&G monitor is equipped with a special hardware routine which attempts to account for this natural background concentration, as will be discussed further.

\subsection{OTHER MONITORING EXPERIENCE}

Currently, radionuclides are sampled continuously and analyzed periodically, off-line, at the TSCA Incinerator according to NESHAP regulations. Sample gas is withdrawn through a short probe and heated filter. The gas that exits the filter is cooled to remove condensed moisture and passes through a series of impingers and drying tubes. The probe wash and filter are analyzed for particulate radionuclides. The condensate and impinger solutions are analyzed for volatile radionuclides. The entire sample train is recovered weekly. Sample-train segments of the same type are composited and analyzed monthly. Radionuclide emissions are calculated based on this analysis, the sample volume collected, and the known total stack gas-flow rate over the period of sampling. Consequently, if there were a large release over a small period of time during the interval of sample collection, it would not be detected until the filter and sampling train were renewed, and then only an average of the emissions over the collection time could be made. One important advantage of the EG\&G monitor is its potential ability to make a very rapid notification of any rise in radionuclide emissions. More detail will be provided on the methods that the monitor uses to perform this notification in subsequent sections. 


\begin{tabular}{|c|c|c|c|c|c|c|}
\hline Nuclide & $\begin{array}{c}1996 \\
\text { Stack } \\
\text { discharge } \\
\text { (Ci) }\end{array}$ & $\begin{array}{c}1996 \\
\text { Stack } \\
\text { discharge } \\
2 \text { sigma } \\
\text { (Ci) }\end{array}$ & $\begin{array}{c}1995 \\
\text { Dose } \\
\text { conversion } \\
(m r e m / C i)\end{array}$ & $\begin{array}{c}\text { Dose to } \\
\text { MEI }^{b} \\
\text { (mrem/year) }\end{array}$ & $\begin{array}{c}1996 \\
\text { Quantity } \\
\text { fed } \\
\text { (Ci) }\end{array}$ & $\begin{array}{c}\text { Potential } \\
\text { dose to } \\
\text { MEI } \\
\text { (mrem/year) }\end{array}$ \\
\hline${ }^{3} \mathrm{H}$ & & & $\mathrm{NA}^{c}$ & & $3.51 \mathrm{E}-01$ & NA \\
\hline${ }^{14} \mathrm{C}$ & & & NA & & $8.00 \mathrm{E}-04$ & NA \\
\hline${ }^{40} \mathrm{~K}$ & 7.30E-05 & $1.10 \mathrm{E}-0.4$ & $2.60 \mathrm{E}-01$ & & & \\
\hline${ }^{51} \mathrm{Cr}$ & & & NA & & & \\
\hline${ }^{57} \mathrm{Co}$ & $-1.15 E-06$ & $3.64 \mathrm{E}-06$ & $6.1 \mathrm{E}-03$ & $-6.99 E-09$ & $4.60 E-05$ & $2.81 \mathrm{E}-07$ \\
\hline${ }^{80} \mathrm{Co}$ & $6.54 \mathrm{E}-04$ & $6.39 \mathrm{E}-04$ & $5.1 \mathrm{E}-01$ & $3.34 \mathrm{E}-04$ & & \\
\hline${ }^{88} Y$ & & & NA & & & \\
\hline${ }^{99} \mathrm{Tc}$ & $6.20 \mathrm{E}-03$ & $3.84 \mathrm{E}-03$ & $3.50 \mathrm{E}-02$ & 2.17E-04 & $3.37 \mathrm{E}-01$ & $1.18 \mathrm{E}-02$ \\
\hline${ }^{10} \mathrm{Ru}$ & & & NA & & & \\
\hline${ }^{109} \mathrm{Cd}$ & & & NA & & & \\
\hline${ }^{131} \mathrm{I}$ & $-1.40 \mathrm{E}-06$ & $7.10 \mathrm{E}-06$ & NA & NA & $5.00 \mathrm{E}-04$ & NA \\
\hline${ }^{137} \mathrm{Cs}$ & $-2.99 \mathrm{E}-04$ & $1.19 \mathrm{E}-03$ & $7.90 \mathrm{E}-02$ & $-2.36 \mathrm{E}-05$ & $8.50 E-03$ & $6.71 \mathrm{E}-04$ \\
\hline${ }^{139} \mathrm{Ce}$ & & & NA & & & \\
\hline${ }^{141} \mathrm{Ce}$ & & & NA & & & . \\
\hline${ }^{201} \mathrm{TI}$ & & & NA & & & \\
\hline${ }^{206} \mathrm{Ra}$ & & & NA & & & \\
\hline${ }^{255} \mathrm{Th}$ & $3.38 \mathrm{E}-06$ & $2.19 \mathrm{E}-06$ & $1.50 \mathrm{E}+01$ & $5.07 \mathrm{E}-05$ & $1.90 \mathrm{E}-03$ & $2.85 E-02$ \\
\hline${ }^{230} \mathrm{Th}$ & $6.29 \mathrm{E}-06$ & $4.29 \mathrm{E}-06$ & $1.50 \mathrm{E}+01$ & $9.43 E-05$ & $2.70 \mathrm{E}-03$ & $4.05 E-02$ \\
\hline${ }^{232} \mathrm{Th}$ & 9.37E-07 & $1.72 \mathrm{E}-06$ & $2.10 E+01$ & $1.97 \mathrm{E}-05$ & $1.30 \mathrm{E}-03$ & $2.73 E-02$ \\
\hline${ }^{23} \mathrm{Th}$ & $4.41 E-03$ & $1.20 \mathrm{E}-02$ & $5.20 \mathrm{E}-03$ & $2.29 E-05$ & $2.59 \mathrm{E}-01$ & $1.35 \mathrm{E}-03$ \\
\hline${ }^{23} \mathrm{~m} \mathrm{~Pa}$ & $2.50 \mathrm{E}-01$ & $1.96 \mathrm{E}-01$ & $4.30 \mathrm{E}-10$ & $1.08 \mathrm{E}-10$ & $5.50 \mathrm{E}-01$ & $2.36 \mathrm{E}-10$ \\
\hline${ }^{24} \mathrm{U}$ & $6.93 \mathrm{E}-04$ & $5.58 \mathrm{E}-05$ & $7.80 \mathrm{E}+00$ & $5.40 \mathrm{E}-03$ & $2.08 \mathrm{E}-01$ & $1.62 E+00$ \\
\hline${ }^{235} \mathrm{U}$ & $1.17 \mathrm{E}-06$ & $8.86 \mathrm{E}-08$ & $4.30 \mathrm{E}+00$ & $5.02 \mathrm{E}-06$ & $9.65 \mathrm{E}-03$ & $4.15 E-02$ \\
\hline $250 \mathrm{U}$ & $3.42 \mathrm{E}-03$ & $2.56 \mathrm{E}-04$ & $6.90 \mathrm{E}+00$ & $2.36 \mathrm{E}-02$ & $2.41 \mathrm{E}-01$ & $1.66 \mathrm{E}+00$ \\
\hline${ }^{2 \pi} \mathrm{Np}$ & $2.35 \mathrm{E}-07$ & $1.55 \mathrm{E}-06$ & $1.90 \mathrm{E}+01$ & $4.46 \mathrm{E}-06$ & $2.00 \mathrm{E}-03$ & $3.80 \mathrm{E}-02$ \\
\hline${ }^{238} \mathrm{Pu}$ & $9.96 \mathrm{E}-07$ & $2.89 \mathrm{E}-06$ & $1.80 \mathrm{E}+01$ & $1.79 \mathrm{E}-05$ & $1.00 \mathrm{E}-03$ & $1.80 \mathrm{E}-02$ \\
\hline${ }^{209} \mathrm{Pu}$ & $-1.37 \mathrm{~T}-07$ & $2.37 E-06$ & $1.20 E+01$ & $-1.65 E-06$ & $5.00 \mathrm{E}-04$ & $6.00 \mathrm{E}-03$ \\
\hline
\end{tabular}

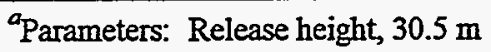
Exit velocity, $5.46 \mathrm{~m} / \mathrm{s}$ Exit diameter, $1.37 \mathrm{~m}$ Exit temperature, $80.55^{\circ} \mathrm{C}$

${ }^{b} \mathrm{MEI}=$ maximum exposed individual.

QNA $=$ not available . 
The Scientific Ecology Group (SEG) Incinerator in Oak Ridge uses Berthold EG\&G radionuclide monitors on its stacks; however, its arrangement is different in several respects from that of the TSCA Incinerator. SEG uses a sampling line, which is over $100 \mathrm{ft}$ in length (consequently, whether a representative sample is obtained is questionable); its stack gas stream is unsaturated with moisture; and its stack temperature is $\sim 150^{\circ} \mathrm{F}$, a temperature which is significantly lower than the TSCA Incinerator stack temperature. In spite of these factors, SEG's problems with moisture condensation and corrosion have been serious, and the effectiveness of SEG's efforts probably has yet to be demonstrated.

The in-situ vitrification process, which was used on the Oak Ridge Reservation, attempted to monitor radionuclides with an AMS, Inc., alpha gas proportional counter. The radionuclides evolved from the high-temperature treatment of soils. The monitor was not designed for these conditions and quickly failed. The precise causes of its failure were not investigated.

The NMC Nuclear Instrumentation Corporation manufactures a monitor which withdraws sample gas at $3 \mathrm{ft}^{3} / \mathrm{min}$, collects sample particulate on a moving roll of filter paper, and passes the filter paper by an alpha-beta scintillation detector. It is not designed to accommodate moistureladen gas streams or high temperatures. These monitors have been used at the Oak Ridge Y-12 Plant for ambient-temperature stack monitoring. The NMC monitor sensitivity is much lower than that of the EG\&G monitor, and the instrument suffers from the same shortcomings as the latter.

\section{APPARATUS DESIGN}

\subsection{MYLAR EXPERIMENTATION}

Because no experience could be found with a radionuclide monitor at conditions resembling those of the TSCA Incinerator, we decided that it was necessary to replicate those conditions as best as possible in the laboratory and to identify the problems with such a design before installation on the TSCA Incinerator stack. The principal and first concern was the high temperature and humidity of the stack gas. The manufacturer reported no particular difficulty with raising the temperature of the monitor to $150^{\circ} \mathrm{F}$; indeed, the monitor had originally been designed to operate at $150^{\circ} \mathrm{F}$ on the now defunct Controlled Air Incinerator at LANL. The manufacturer thought that the chief concern in raising the temperature of the gas flowing through the monitor to a higher temperature would be in the resistance or stability of the aluminized Mylar film, a high-strength 
polyester plastic vacuum coated with a thin layer of aluminum. Accordingly, before further work, we placed a sample of the Mylar film in a laboratory furnace, in the absence of humidity, for a test of the creep resistance of the material. Later, further data were forthcoming from EG\&G Berthold which indicated that no qualitative problems were encountered with the Mylar to temperatures of $95^{\circ} \mathrm{C}\left(203^{\circ} \mathrm{F}\right)$.

The Mylar film, of $0.47 \mathrm{mg} / \mathrm{cm}^{2}$ for the beta detector and $0.41 \mathrm{mg} / \mathrm{cm}^{2}$ for the alpha detector (area density), was placed under a load of $25 \mathrm{~g}$ in tension for a period of 2.5 months at 105 to $110^{\circ} \mathrm{C}\left(222\right.$ to $\left.230^{\circ} \mathrm{F}\right)$. A gage length of $14 \mathrm{~cm}$ and a width of $5 \mathrm{~cm}$ were used. No elongation was observed beyond $0.1 \mathrm{~cm}$ or $(0.7 \%)$ over this period. The furnace was used for other purposes so that the temperature was subject to some fluctuations. The $25-\mathrm{g}$ weight was selected on the basis of stresses that EG\&G reported that the film would be exposed to during the installation process. The Mylar film eventually failed because of a small tear which widened when the film was handled. In fact, tearing is the most likely mode of failure because the Mylar is extremely strong in simple tension. The manufacturer, Dupont, ${ }^{2}$ reports a similar value in its product literature [ 0.6 to $0.9 \%$ dimensional stability at $\left.105^{\circ} \mathrm{C}\left(222^{\circ} \mathrm{F}\right)\right]$. The Mylar film is sensitive to moisture, its tensile strength and elongation diminish linearly with increasing time at $100^{\circ} \mathrm{C}$, and it - becomes more brittle as well. The Mylar film is coated with a thin layer of aluminum that is impenetrable to water and serves to discharge the buildup of static electricity on the film. Any damage to the aluminized film, however, would lead to water penetration and a significant loss in the film's creep resistance. A further problem with gas penetration, and one which may have been encountered, is the contamination of the $\mathrm{P}_{10}$ (90 vol \% argon, $10 \mathrm{vol} \%$ methane) proportional detector fill gas. ${ }^{3}$

\subsection{HUMIDIFICATION APPARATUS}

The favorable results with the Mylar film encouraged us to proceed with the next step, which was to construct an apparatus to humidify air to saturation at a range of temperatures between 180 and $190^{\circ} \mathrm{F}$. This range of temperatures, interestingly, can mean an enormous difference in the quantity of moisture, which increases exponentially with temperature. At $180^{\circ} \mathrm{F}$, it is $0.6578 \mathrm{lb}$ of water per pound of dry air and at $190^{\circ} \mathrm{F}$ it is $1.1 \mathrm{lb}$ of water per pound of dry air or nearly $50 \mathrm{wt} \%$ water at temperatures slightly above TSCA Incinerator conditions. The problem is to mix ambient air at some average humidity with water, steam, or heat to produce a saturated air stream 
at $190^{\circ} \mathrm{F}$. This problem involves the establishment of a simultaneous heat and mass balance of water and air. The maximum gas-flow rate at which the EG\&G monitor operates is in the range of 25 standard cubic feet per minute ( $\mathrm{scfm}$ ), so we wanted to produce a flow rate of at least this magnitude and then be able to regulate it.

Three alternatives were considered: (1) the purchase of a commercial humidifier, (2) the use of a furnace which would produce a high-temperature gas stream which is then adiabatically quenched, such as that which occurs in the actual incineration, and (3) a modified venturi in which steam and air are mixed together in the correct proportions and at the correct pressure to yield a saturated stream. Commercial humidification equipment (such as water-spray chambers which produce a humid air stream in excess of $150^{\circ} \mathrm{F}$ ) was not available. Indeed, the reference-book humidity charts do not even consider saturated air above $150^{\circ} \mathrm{F}{ }^{4}$ The Savannah River Laboratory (SRL) Technology Center Off-gas Components Test Facility was also considered as a possible site at which to conduct the experimentation because it is already designed to produce a gas stream meeting our requirements, but reports indicated that it would be expensive to operate and that the logistical difficulties in conducting tests at SRL outweighed the expense of building our own apparatus, which could be, in principle, more flexible. Accordingly, we chose the third alternative partly based on the results of W. Davis ${ }^{5}$ at The University of Tennessee, who mixed steam and air on a massive basis, in the order of hundreds of cubic feet per minute (cfm), to produce a simulated TSCA Incinerator stack gas for experimentation with a pilot-scale air-pollution control system.

Davis was not greatly concerned about the problems of excess water droplets; however, his system could tolerate massive slugs of water which would be an unrealistic scenario of TSCA Incinerator stack gas. Usually, the TSCA Incinerator runs fairly close to saturation with some "raining" in the stack during cool weather. We required a system which would separate the steam which condensed in the process of heating the ambient air to saturation at 180 to $190^{\circ} \mathrm{F}$. A Mathcad routine was written to perform the mass and heat balance and solve the simultaneous equations. A schematic of the mass balance is shown in Fig. 3 around the humidification apparatus. The spreadsheet calculations supporting our design are shown in Appendix A. These calculations showed that with $150 \mathrm{psi}$ steam, for example, we could generate a saturated air flow of $40 \mathrm{~m}^{3} /$ hour (approximately $7 \mathrm{dry} \mathrm{cfm}$ at $68^{\circ} \mathrm{F}$ ) using $33 \mathrm{lb}$ of steam per hour and $33 \mathrm{lb}$ of air, while generating a condensate flow of $0.5 \mathrm{lb} / \mathrm{h}$. These conditions would produce a saturated air 
ORNL DWG 97C-396

$33 \mathrm{Ib} / \mathrm{h}$

AMBIENT

AIR, $77^{\circ} \mathrm{F}$

$\sim 150$ psig

STEAM

$33 \mathrm{lb} / \mathrm{h}$

HUMIDIFICATION

CHAMBER

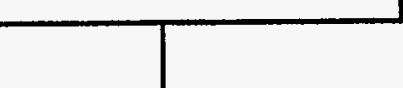

HUMID AIR

$190^{\circ} \mathrm{F}$

SATURATED

$65 \mathrm{lb} / \mathrm{h}$

CONDENSATE

$190^{\circ} \mathrm{F}$

$0.5 \mathrm{lb} / \mathrm{h}$

Fig. 3. Schematic of humidification-apparatus mass balance. 
stream at $190^{\circ} \mathrm{F}$, which was an appropriate design-target temperature, slightly above the actual stack conditions.

The apparatus, as shown in Fig. 1, fed the steam through an orifice, similar to a steam-jet eductor, and drew in some ambient air by the vacuum it generated. We did not rely on this effect, however, to achieve our desired flow rates. Each of the Rotron EN/DP 523 blowers, provided with the EG\&G monitor, have a capacity of about $25 \mathrm{scfm}$ at $90 \mathrm{in}$. of water vacuum and were used to provide the suction through the apparatus. The total flow rate was adjusted by throttling the Rotron blower, and the steam flow rate was adjusted using a service-regulating ball valve. The valve was sized to have the appropriate trim to regulate flow of steam between 1 and $50 \mathrm{lb} /$ hour steam. The steam and air flowed to a liquid-gas separator drum from which condensate was drained at the bottom and steam and air were mixed together. The steam-air mixture temperature was monitored, and the combined stream was fed to the heat-exchange apparatus.

\subsection{SAMPLE GAS CONDITIONING}

In preface to a discussion of the heat-exchanger design, we should state why this particular design was selected to achieve our end objective, which is radionuclide particulate monitoring. It is possible to cool a stream of stack gas, condense the water, and feed the cool air to the monitor for radiation monitoring. The chief difficulty with this approach, however, is that the condenser will also function as an effective scrubber of particulates. In fact, scrubbers are designed based on the principle of condensation using fine particulates as condensate nuclei. The collection efficiency of scrubbing can be increased by greater than $50 \%$ by the simultaneous condensation of water vapor from the gas stream. ${ }^{6}$ The second problem is that the quantities of moisture to remove from a gas stream would not be insignificant. Witness the approximate $40 \mathrm{wt} \%$ water of a stream saturated at $182^{\circ} \mathrm{F}$, for example. This hypothetical case would result in $30 \mathrm{lb}$ of water per hour being removed from the sample stream by condensation in order to achieve a room temperature gas stream for introduction into the monitor.

A second possible approach to the problem is the dilution of a stack-gas stream with heated ambient air in order to reduce the humidity of the stack gas. If unheated ambient air is used to dilute the sample stream, condensation again occurs, and the same difficulty as that with the first alternative would be encountered. If the dilution gas were heated, then why should not the entire stream be heated? In addition, the dilution gas reduces the sensitivity of the detector because there 
is less actual incinerator gas available to pass through the monitor. For example, if equal amounts of bone-dry air and saturated air at $183^{\circ} \mathrm{F}$ were mixed together, the dew point would be reduced to only $\sim 165^{\circ} \mathrm{F}$. The monitor would still have to be heated above this temperature to prevent condensation within it. We would then have halved our available sample for a lowering of the operating temperature by only $18^{\circ} \mathrm{F}$. In addition, the design of such a dilution apparatus would require an on-line measurement of the humidity and temperature of the incoming air which, though possible, would complicate the operation. In spite of these drawbacks, the dilution option may be worth exploring if the monitor should fail to function above $165^{\circ} \mathrm{F}$ because of proportional counter stability, as will be discussed.

\subsection{HEAT EXCHANGER DESIGN}

For the reasons stated in Sect. 2.3 and partly from simplicity of design, we chose to construct a heat exchanger to heat an undiluted sample of stack gas above its adiabatic saturation temperature to prevent the formation of condensate within the monitor. Since the Mylar had been found to function well in the laboratory to a temperature of $220^{\circ} \mathrm{F}$, we chose this temperature as an operating temperature because it provides a margin of greater than $30^{\circ} \mathrm{F}$ above the adiabatic saturation temperature. (Thirty degrees above the adiabatic saturation temperature was the design value for the former LANL Controlled Air Incinerator.)

Several important factors needed to be considered in the heat exchanger design. The heat exchanger will be subject to chloride ion attack from hydrogen chloride and dissolved sodium chloride in entrained water droplets from the stack. The heat exchanger must be compact to fit on the stack. It must operate at a duty of $\sim 2 \mathrm{~kW}$. It must be no longer than necessary because there is a continual loss in particulates with increasing length of the sample line or the heat exchanger. It must not have any sharp bends or other obstructions on which particulate could impinge. It is this latter requirement which places the needs of our project outside the availability of commercial equipment.

Commercial manufacturers offer small-capacity, low-flow gas heaters which are in the range of the required duty but which feature sheath-heating elements, and although quite efficient, directly obstruct the flow within the tube. The tube design features a $90 \%$ bend which we think is highly undesirable. High-temperature air-duct heaters are available, also. These could meet our process temperature requirements, but unfortunately they have several serious drawbacks for 
sampling stack gases. These heaters have a large number of bend-tube heating elements which pass directly through the process gas. They were designed for air primarily; consequently, they do not have the acid gas or chloride resistance that we require. They are also large, having typical dimensions in the order of 2 by $3 \mathrm{ft}$ and are configured for rectangular ducts. High-efficiency particulate absolute (HEPA) filters usually use a preheat section of this design. Of course, the option of custom ordering a unit is available, but since the manufacturer had not considered this specific problem earlier, we elected to design and construct one in-house.

The heating of gases is inherently difficult because of their low thermal conductivity and density. The Sieder Tate correlation, also known as the Chilton-Colburn correlation, relates the Prandtl, Nusselt, and Reynolds numbers empirically from which the heat transfer coefficient $h$ can be calculated. A sample calculation is shown in Appendix B in a spreadsheet routine. The applicable equation is:

$$
\mathrm{Nu}(\mathrm{d})=0.023 \mathrm{Nre}(\mathrm{d})^{0.8} \cdot \mathrm{Npr}^{\frac{1}{3}}
$$

where $\mathrm{Nu}$ is the Nusselt number, Nre is the Reynolds number, Npr is the Prandl number, and $\mathrm{d}$ is the diameter. As noted in Appendix B, the heat transfer coefficient $h$ rises strongly with a drop in the diameter of the tube through which gas is flowing. Because we desired a high heat flux per unit length, we chose a $13 / 8$-in.-diam. pipe wrapped with Calrod ${ }^{\mathrm{TM}}$ ceramic-coated heating elements. Three separately programmable heat exchangers in series were selected to offer some greater versatility in control. A capacity of $2.5 \mathrm{~kW}$ was set to provide a margin against the possibility that droplets of water might be entrained in the entering gas. Such droplets (because of their high latent heat of evaporation) place a high duty requirement on the heat exchanger, a much more significant requirement per unit weight than the sensible heat requirement of the saturated air itself.

The heating section was constructed of type-316 stainless steel because it had been found acceptable in long-term incinerator-sampling probe applications in the past. Inconel ${ }^{\text {TM }} 601$ was preferred for long-term service because, in this application, the wall temperatures are greater and the possibility of increased deposition of sodium chloride can enhance stainless steel corrosion in a sense that it cannot with Inconel. Inconel was unavailable, however, and in the interest of expediting the study, stainless steel was accepted. Stainless steel, if kept dry, should perform well. Hastelloy ${ }^{\mathrm{TM}}$ was another alternative, but it was not recommended because of its weak resistance to 
sulfur reactions, relatively weak high-temperature performance, ${ }^{7}$ and unavailability. The heat exchanger consists of three 0.315 -in.-diam round cross-section tubular component heaters, 500 , 900 , and $1050 \mathrm{~W}$, respectively, at $110 \mathrm{~V}$. The $110-\mathrm{V}$ rating is compatible with TSCA Incinerator stack power availability. The heaters consist of an Incoloy sheath, $30 \mathrm{~W} / \mathrm{in}$., $1600^{\circ} \mathrm{F}$ maximum temperature rating. The heater tubing was wound on a 4-in. pitch around the outside of the 1-in. stainless steel pipe and wrapped with a stainless steel sheet to equalize the temperature distribution. The stainless steel sheet was then wrapped with fiberglass-tape insulation. An initial attempt to insulate the heated section with Rubetex ${ }^{\text {TM }}$ high-temperature rubber insulation failed, and the rubber charred. The lengths of the heated sections were 22,34 , and 38 in., respectively, on heaters 1,2 , and 3 .

\section{RESULTS}

\subsection{INITIAL STEAM-CART TESTING}

The first phase of testing was to determine if the steam cart (as we called the humidification apparatus since it was installed on a portable cart) worked at the approximate design flow rates. As noted, the only precedent for this design was that of $W$. Davis at The University of Tennessee. ${ }^{5}$ It was observed that the unheated sections of the apparatus required insulation or else the condensation was excessive. The condensate separator drum tended to fill completely with water and required frequent draining. Fiberglass insulation was chosen for the straight-pipe, steamcarrying sections of the apparatus (Fig. 1). Cast insulation was used on other sections. After this difficulty was resolved, we found that the heat exchangers could produce a superheated air-steam mixture at the proper flow rates.

\subsection{MONITOR EXPERIMENTATION}

\subsubsection{Calibration}

While the steam cart was in construction, the monitor was adjusted in four steps: (1) plateau voltage was set, (2) local background alpha and beta radiation measurements were performed, (3) alpha and beta efficiencies were established using a calibration standard, and (4) a correction 
curve was made for the natural activity. This last correction is known also as the pseudocoincidence correction.

The plateau voltage is a specific voltage value at which the sensitivity for alpha radiation (and alpha radiation alone) is optimized. The alpha radiation may occur in a spectrum of energies; therefore, an energy discriminator is part of the circuitry of the instrument. The lower energy range discriminator fixes the value of the lowest energy radiation which is recorded. (An upperrange energy discriminator is also used to distinguish between radon and actinide alpha radiation because the actinides generally have higher alpha energy activity. This range is not adjustable in the field, however.) If the plateau voltage is set too high, extraneous radiation, such as backscatter and beta pulses, can be recorded; and, if set too low, a certain fraction of the real alpha will be lost. We initially used an ${ }^{241} \mathrm{Am}$ source as our source of radiation while the plateau voltage was determined. This source was quite small in relation to the total area of the counter; the counter was larger than its typical counterparts to maximize sensitivity. This resulted in a platform voltage which was abnormally high (in the range of $2000 \mathrm{~V}$ ) and likely to result in poor sensitivity. ${ }^{8}$ An initial concern was a malfunction in the high-voltage power supply, but no problems were found with it. We tried a number of difference radiation sources $\left({ }^{238} \mathrm{U},{ }^{99} \mathrm{Tc},{ }^{241} \mathrm{Am}\right)$ unsuccessfully. Consultations with EG\&G revealed that, conventionally, the plateau (and calibration, as will be noted) was set using a special 194-mm (7.63-in.) pancake source which incorporates a radionuclide (in our case, ${ }^{238} \mathrm{Pu}$ ) into an anodized aluminum foil of $6-\mu \mathrm{m}$ thickness. ${ }^{9}$ Such a source was available from Amersham Corporation, Arlington Heights, Illinois. A similar beta source was procured which incorporates ${ }^{90} \mathrm{Sr}$. Using these special sources, the alpha plateau was reasonably established at $1250 \mathrm{~V}$; and the beta, at $2100 \mathrm{~V}$, which are typical values. The plateau curves and data are exhibited in Appendix $C$.

It should be noted that the design of this monitor is different from that of most alpha-beta monitors in that the anode wire is a long, serpentine wire, which is strung somewhat like the string of a tennis racket (with the cross stitching, however) and is for a source of radiation to be distributed uniformly over the surface of the underlying filter. This implies that the sample distribution across the filter is a significant parameter and should be uniform.

Next, the background counting rate was established. For this procedure, it was necessary to run the Rotron blowers at $25 \mathrm{scfm}$ and pull a sample through the monitor and allow it to collect on the 8-in.-diam filter. Typically, a number of background cycles are run, and the results are 
averaged. We chose a cycle time of 1 hour and 48 cycles. Background counts were collected for the alpha, beta, and gamma guard counters. The results of the background count rates were as follows:

\begin{tabular}{lcccc} 
Radionuclide & Background counts/min $(\mathrm{cpm})$ & \multicolumn{2}{c}{ Standard deviation } \\
Alpha & 1.6 & & Calculated 0.163 & Predicted 0.18 \\
Beta & 111.8 & Calculated 1.365 & Predicted 1.52 \\
Gamma & 287 & Calculated 2.189 & Predicted 2.44.
\end{tabular}

These results were reasonable. The standard deviation for a number of counting intervals such as there were here can be expressed in Eq. (3). ${ }^{10}$

$$
\sigma_{\mathrm{N} \text { intervals }}=\left(\frac{\mathrm{n}_{\text {average }}}{\mathrm{N}}\right)^{0.5}
$$

where $n_{\text {average }}$ is the average number of counts in the $N$ intervals, and $N$ is the number of intervals. The calculated and predicted standard deviations are quite close.

The background count adjustment was performed periodically, but little difference in the laboratory was detected from one counting to the next. The background count can measure effects such as the presence of nearby sources of fixed radioactivity in cinder-block walls, for example. The $\mathrm{P}_{10}$ gas flow rate was fixed at $0.8 \mathrm{~L} / \mathrm{min}$.

The efficiency of the alpha and beta channels was determined following the background determination. For this procedure, it was necessary to resort again to the special Amersham calibration sources. A measurement time of 1 hour was chosen. The calibration factors were 3.67 alpha and 2.07 beta, which are in the acceptable range for these isotopes, according to the manufacturer. We had first observed the effects of the improper settings of the plateau voltages when we obtained seriously high calibration factors (e.g., of the order of 60 for alpha radiation).

The final procedure in the instrument initial configuration was the adjustment for radon or "natural radioactivity" as the manufacturer calls it. The pseudocoincidence utility, which is electronically hard-wired in the instrument, allows for only a few user-set parameters, the measuring time and the number of measurements. Otherwise, the instrument makes all 
determinations (such as the proper energy discrimination values) to screen radon from "artificial activity" (such as uranium, which has higher energy alpha than radon alpha daughters) and the pseudocoincidence parameters. We chose 60 hour-long measurements for this configuration during fair weather. The objective was to conduct a measurement over a period of several days since the alpha activity varies by a factor of 1000 during different times of day. It can vary during periods of wet weather, atmospheric pressure, and with the season as well. Rain, in particular, scrubs radon from the atmosphere and increases ground-level activity. The pseudocoincidence measurement is a means of detecting radon activity uniquely by identifying the occasions when an alpha particle is detected within $\sim 160 \mu \mathrm{m}$ of a beta decay. Pseudocoincidence means that these occasions are occurring at almost the same time. This correction suffers from the fault that there may also be random coincidences of the detection of alpha and beta radiation as well. The random coincidences can be distinguished by their pulse height as compared with the pulse heights of the radionuclides in the radon decay chain which characterize the pseudocoincidences which the instrument seeks to subtract from the actual reading. The pseudocoincidence readings were as follows:

$\begin{array}{lcc} & \text { Alpha } & \text { Beta } \\ \text { Pseudocoincidence factor } & 2.369 \text { Unitless } & 4.394 \text { Unitless } \\ \text { Rate factor } & 0.002 \text { Unitless } & 0.001 \text { Unitless }\end{array}$

These readings compare reasonably well with typical readings from the manufacturer. The complete listing of pseudocoincidence data is shown in Appendix D. The graph in Fig. D.1 (see Appendix D) indicates a diurnal variation in the radon readings in the absence of any artificial sources of radiation. The data then gyrate around a zero reading of radiation, as would be expected if the utility were functioning correctly. The utility also makes an initial correction when the filter is first placed into the instrument because for a period of time the radon daughter activity will build up until secular equilibrium is reached.

\subsubsection{Results of Activity Measurements}

The first objective of this investigation was to determine if the instrument met its claimed sensitivities, in particular, for alpha activity. The monitor can be adjusted to varying lengths of 
counting times. A long and short time are specified. The long time is the time interval at which each of the data is reported either by printer or directly to a computer using the file-capture capability of SMARTERM-340 ${ }^{\text {TM }}$ software. The short time is an integral divisor of the long time and is used to trigger an alarm if certain threshold rates are exceeded. It, therefore, permits a rapid detection of a large release of radioactivity, for example. To make a reasonable comparison of different quantities of activity, a consistent long and short time must be chosen. Without any source of radiation, in an effort to examine the activity in the laboratory atmosphere, we set the detector at a data collection long time of 1 hour and an air-flow rate of about $40 \mathrm{~m}^{3} / \mathrm{h}$. The alpha activity varied between a nonreading (zero reading) and an average (near $1 \mathrm{E}-11 \mathrm{Ci} / \mathrm{m}^{3}$ ) for a 1-hour sample collection. This finding is close to the claimed sensitivities of $3 \mathrm{E}-12 \mathrm{Ci} / \mathrm{m}^{3}$ after 1 hour of sample collection.

In a related test, we chose to use increasingly smaller amounts of a thorium source, a Coleman lantern mantle, as a source of thorium alpha activity. The Rotron blower was not used in these initial experiments because we were interested primarily in the response of the instrument to the artificial source we had introduced and not yet interested in the performance of the pseudocoincidence utility. Radon is not a problem when no gas is flowing through the instrument. Small amounts of radon which might be introduced in the beginning of the run decay with time. The thorium presented a constant source which should not be subject to the same statistical variations as in the experiment discussed just previously. This adjustment did indeed yield much better statistics, and with a reduced amount of thorium, eventually reached a level which was near the detection limits of the instrument. We had a fairly consistent average reading of $2 \mathrm{E}-11 \mathrm{Ci}$ with a $0.474-\mathrm{g}$ source of thorium mantle. We do not know the purity of the source, and we have no way to easily correct for the effect of the geometry of such a small source. When the sample size was reduced to $0.0036 \mathrm{~g}$, which is below the purported sensitivities of the instrument, we had a consistent 0.0 radiation reading in the alpha and beta channels. We did a brief experiment to determine the effects of the counting time on the sensitivity of the alpha detection using the thorium mantle source.

The results are shown in Table 2. They indicate that, for counting times less than $24 \mathrm{~min}$, we were unable to achieve a measurable rate and that there was no appreciable difference between the 60 - and the 45 -min counting interval. They further indicate that a large variance probably exists in 
the data, although the number of measurements did not allow for variances to be established. Further measurements and statistical tests were the next step.

\begin{tabular}{|c|c|}
\hline \multicolumn{2}{|c|}{ Table 2. Effect of counting time of a small thorium source } \\
\hline $\begin{array}{c}\text { Counting time } \\
\text { (min) }\end{array}$ & $\begin{array}{c}\text { Approximate average } \\
\text { radioactivity reading (Ci) }\end{array}$ \\
\hline 60 & $1.6 \mathrm{E}-11$ \\
\hline 45 & $2 \mathrm{E}-11$ \\
\hline 30 & $1 \mathrm{E}-11$ \\
\hline 24 & $\sim 0.0$ \\
\hline
\end{tabular}

\subsection{STATISTICS OF COUNTING}

The results of the alpha readings of the thorium string source are provided in Figs. 4 through 8 at counting times (i.e., long times of $0.06,0.6,6,12$, and $60 \mathrm{~min}$, respectively). The corresponding short times are one-half of the above values. The figures (except Fig. 6) have the same vertical scale for comparative purposes, but the horizontal scales, although all in minutes, cover different time spans. The average radiation readings and standard deviations of the counts are provided in Table 3, except for the 0.06-min counting time, which appears perfectly random, and a standard deviation was not calculated. In these instances, unlike in the previous data, the Rotron blowers were in operation; consequently, we were measuring radon background radiation, and the instrument was making the pseudocoincidence corrections. These fluctuations are superimposed on the statistics. The ayerages are based on samples of ten counting intervals in each case.

\begin{tabular}{|c|c|c|}
\hline \multicolumn{2}{|c|}{ Table 3. Counting statistics with thorium source } \\
\hline $\begin{array}{c}\text { Counting time } \\
\text { (min) }\end{array}$ & $\begin{array}{c}\text { Average } \\
\text { counts/s }\end{array}$ & $\begin{array}{c}\text { Standard } \\
\text { deviation }\end{array}$ \\
\hline 0.6 & 17.5 & 5.23 \\
\hline 6 & 14.5 & 1.44 \\
\hline 12 & 13.5 & 0.838 \\
\hline 60 & 15.4 & 1.26 \\
\hline
\end{tabular}




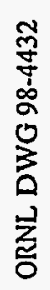

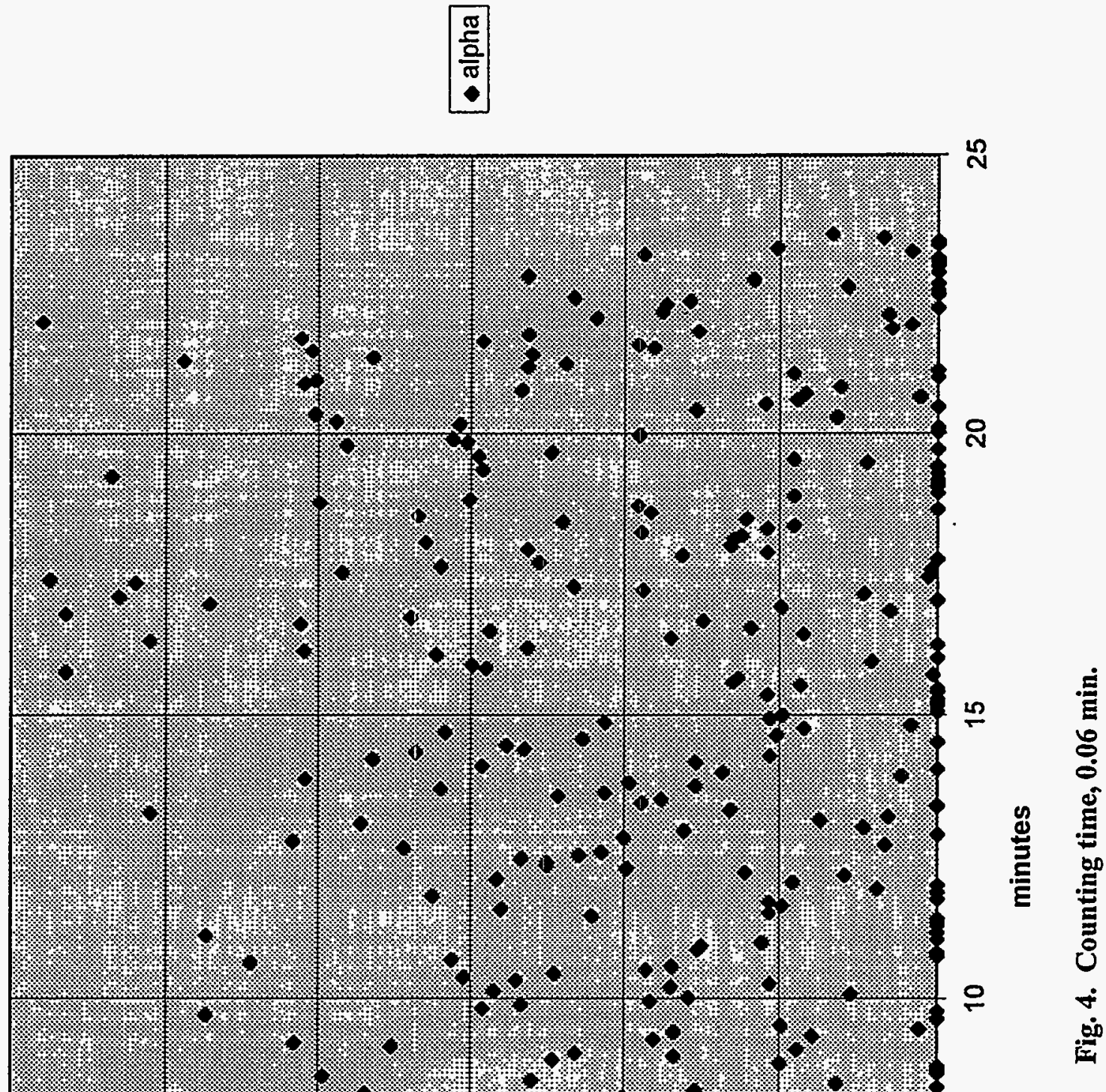

똥
$\frac{0}{\overline{0}}$
0 


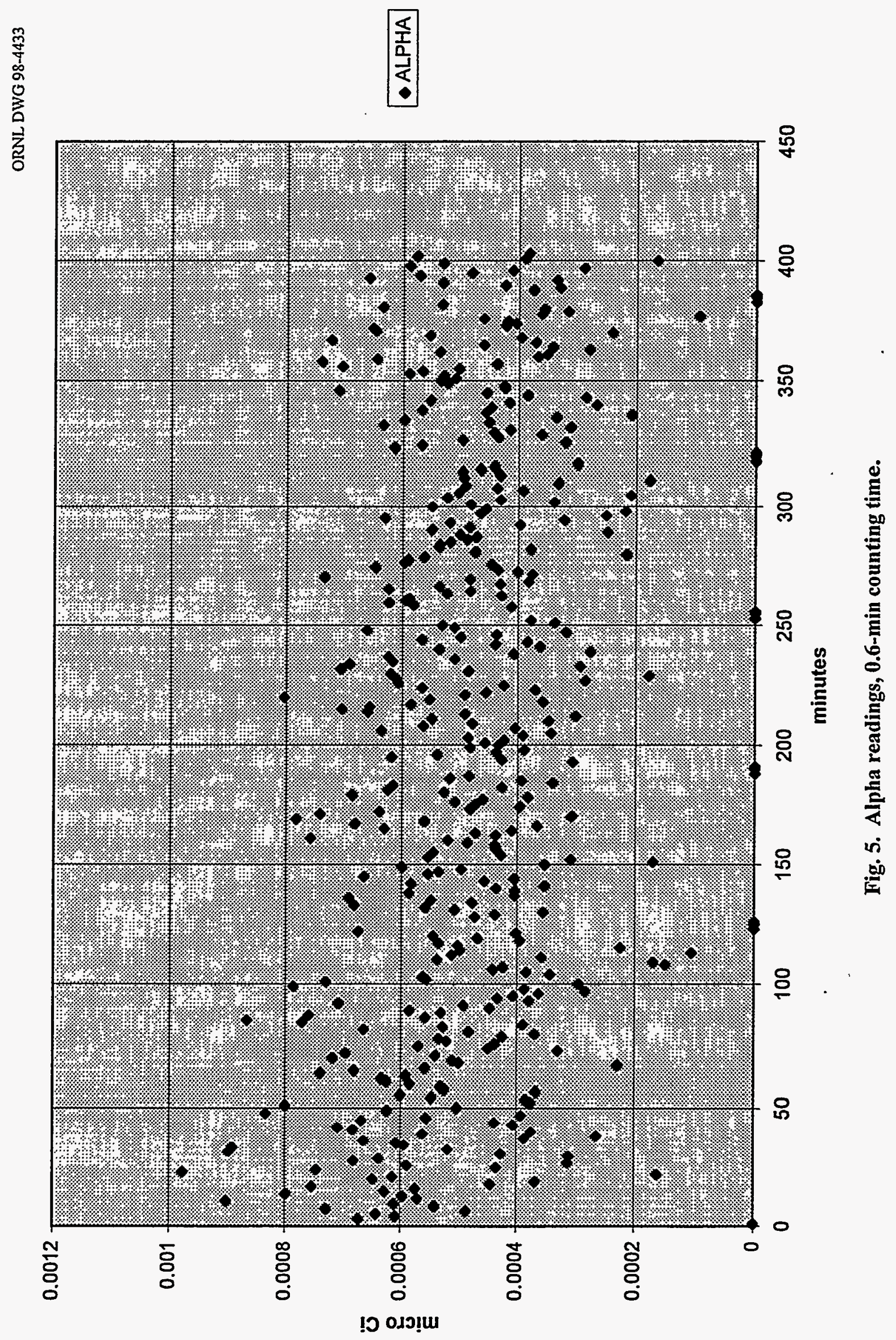




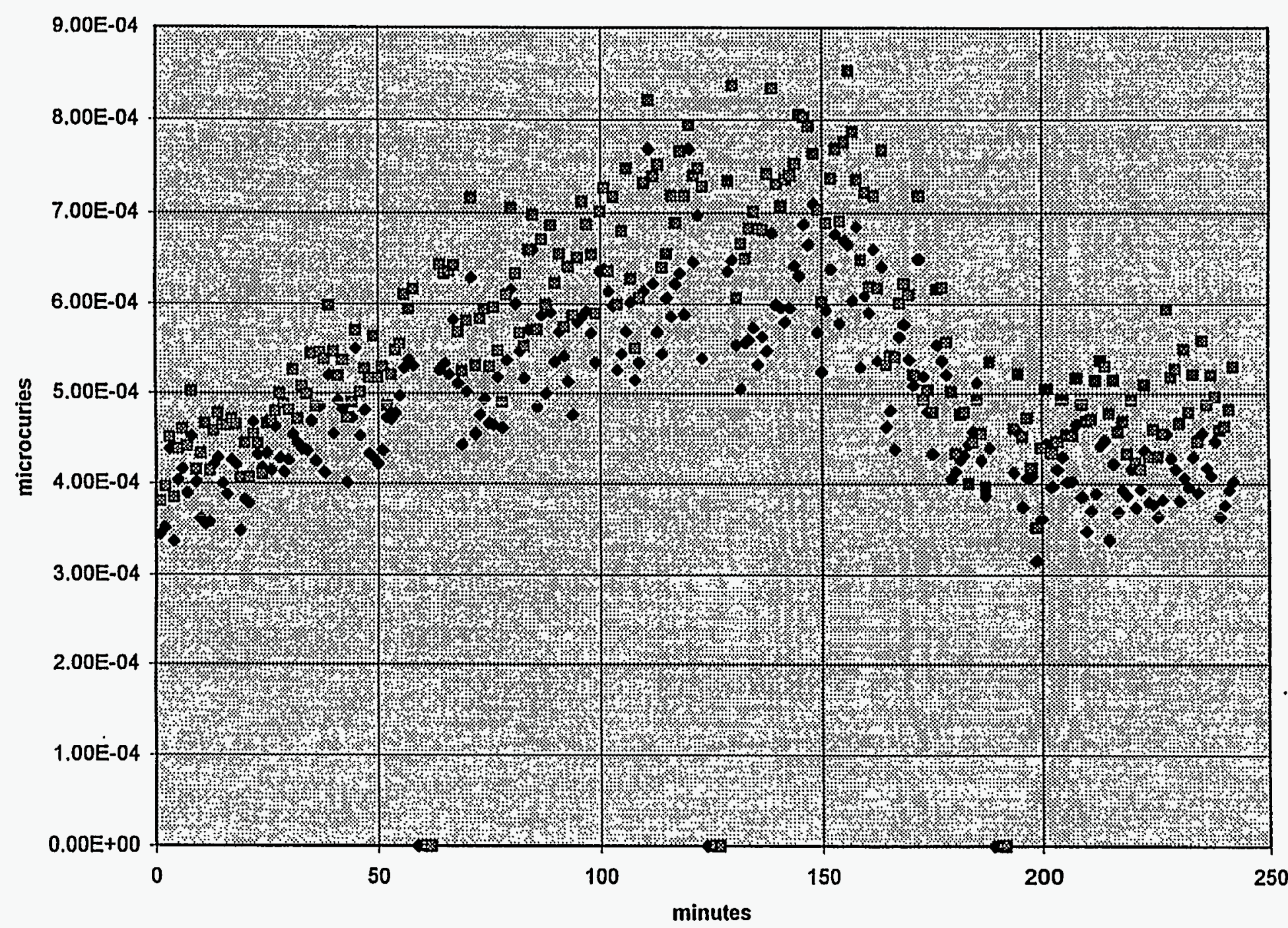

Fig. 6. Alpha readings, 6-min counting time. 


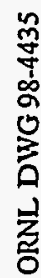

\begin{tabular}{|l}
\hline$\frac{1}{1}$ \\
$\frac{1}{2}$ \\
$\frac{1}{\alpha}$ \\
0
\end{tabular}

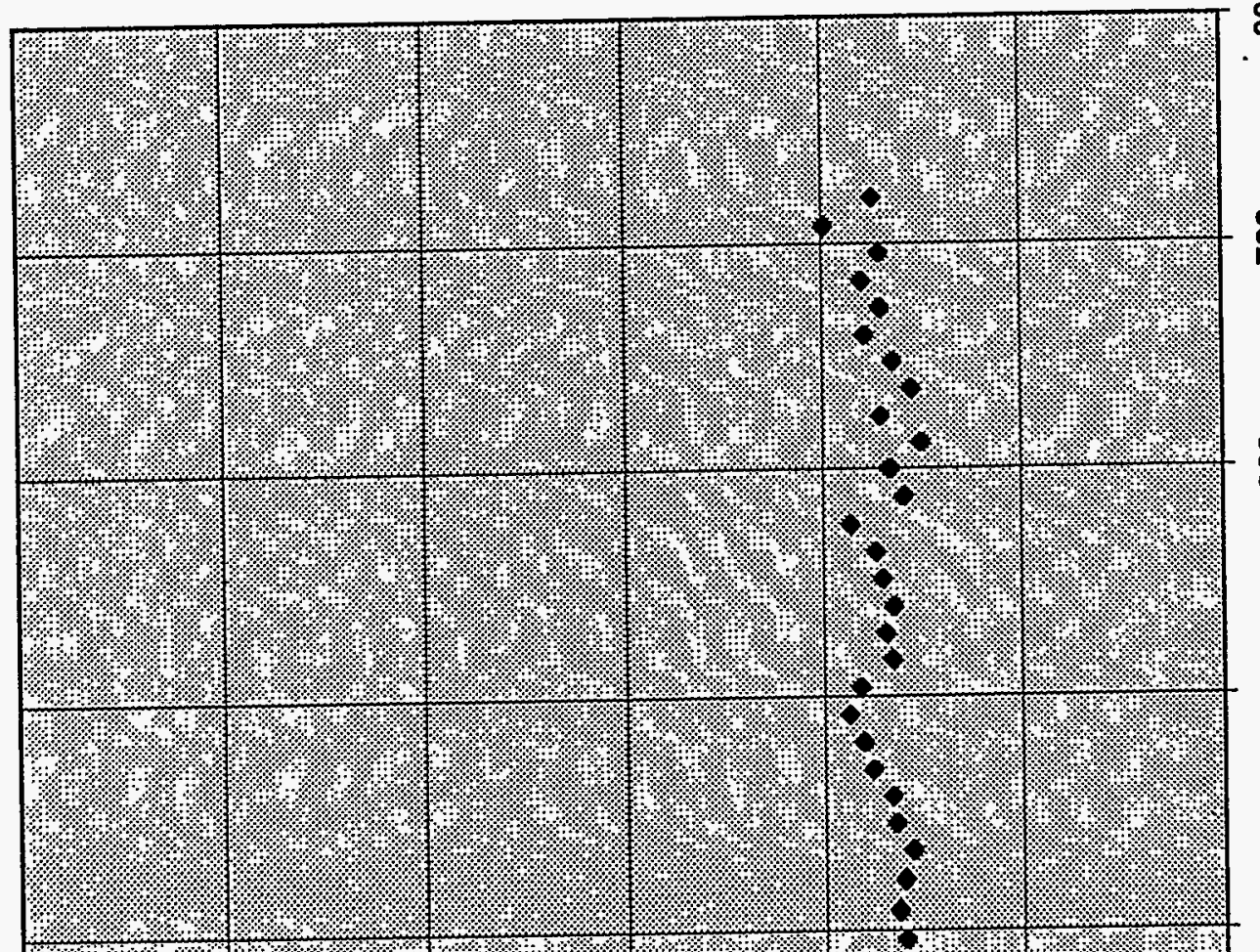

용

용

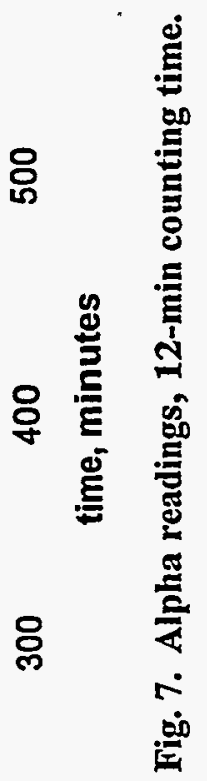

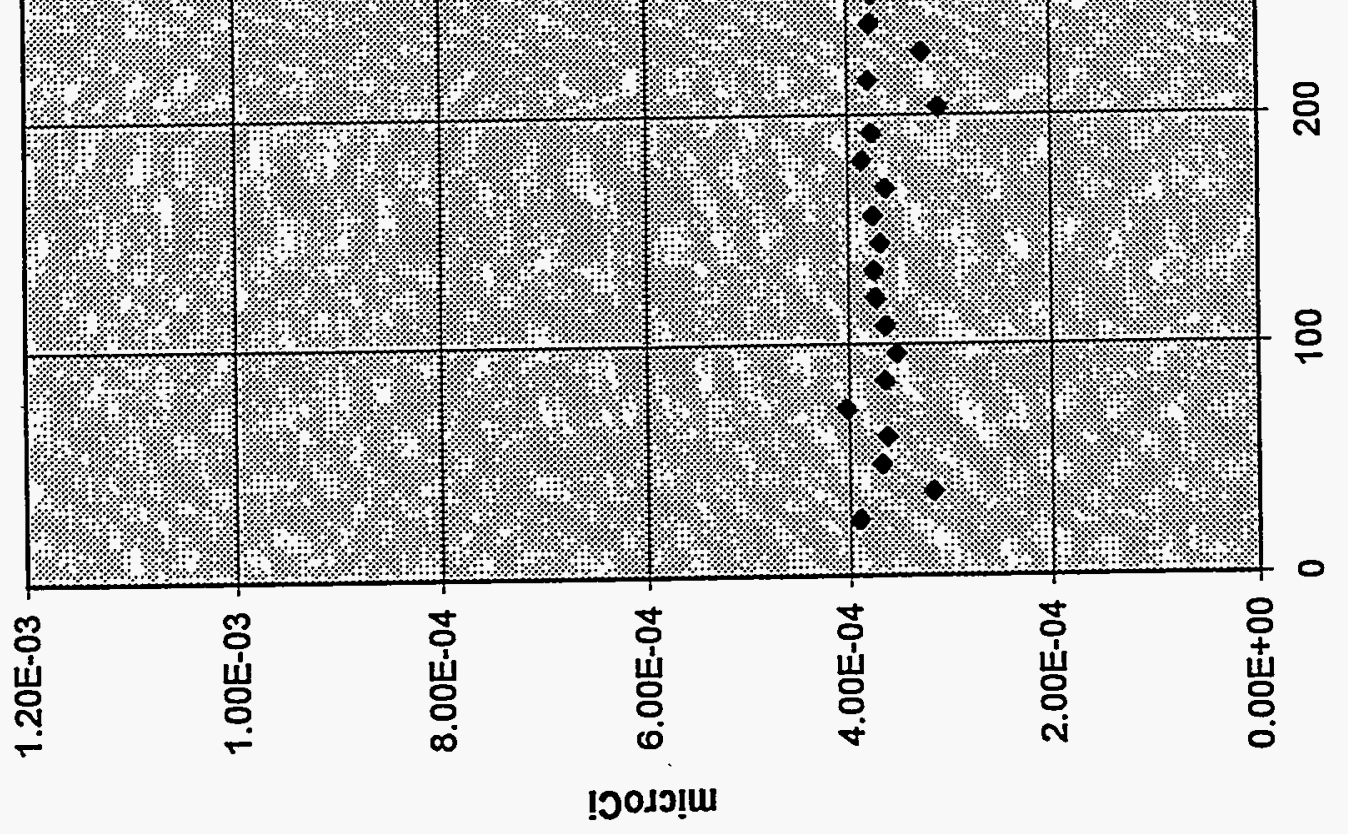




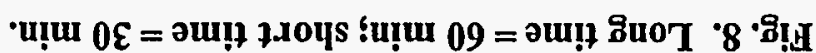

$$
\text { u!m }
$$

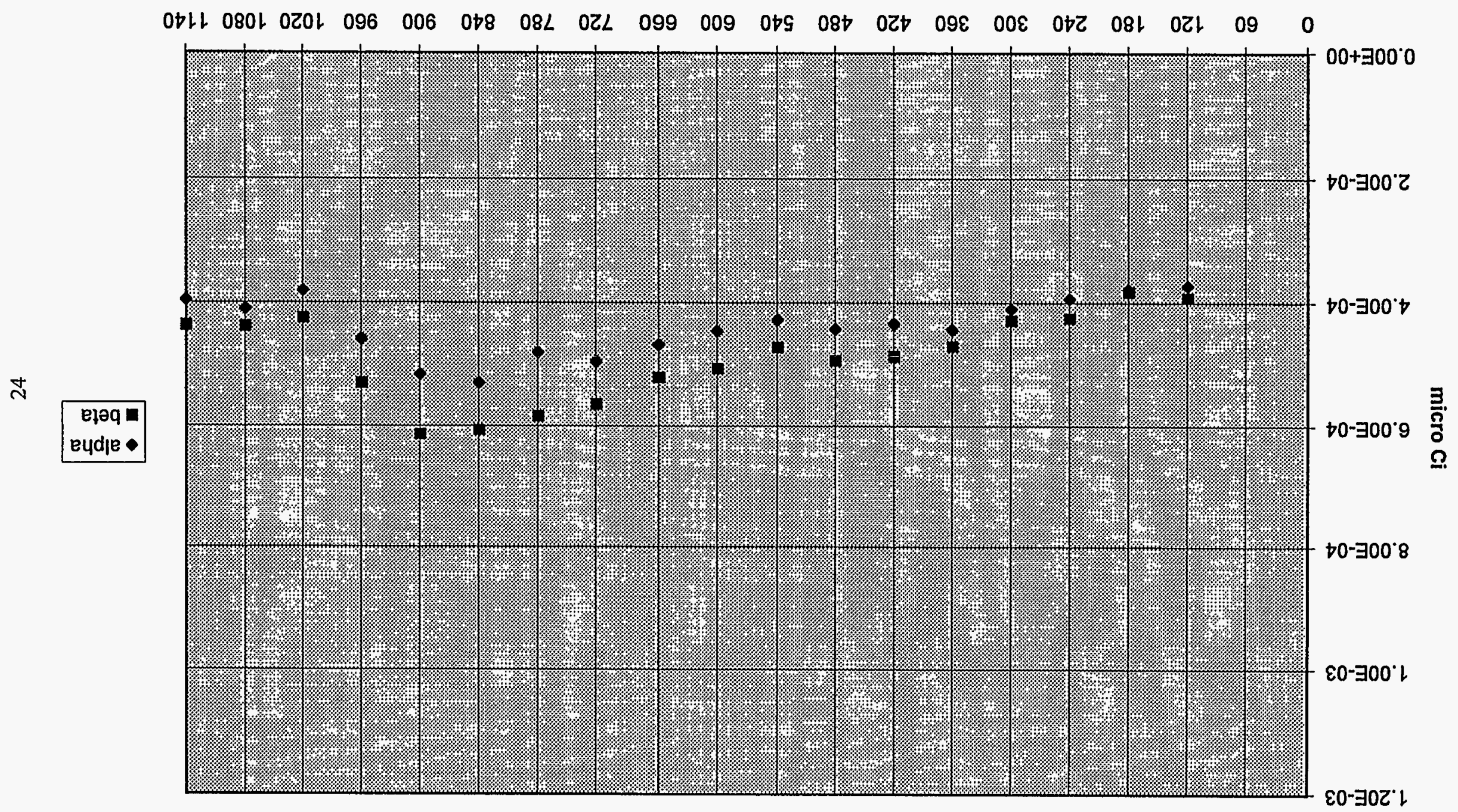

9Ebb-86 DMa TNRO 
It can be observed from this table that the standard deviation usually declines as the counting period is increased. In this case, we are counting a sample in the presence of a background, and the standard deviation arises from variances in the counting statistics of the source and the background.

$$
\sigma_{\text {total }}=\sqrt{\sigma_{\text {background }}^{2}+\sigma_{\text {source }}^{2}}
$$

One interesting point is that there is no advantage in using this particular set of measurements in moving from a 12- to 60-min counting interval. A chi-squared "goodness of fit" test was applied to experiment "Bert15," on September 5, 1997, with a 6-min counting time. The data were normally distributed at the $95 \%$ confidence interval with a chi-squared value of 9.68 with 60 data points, and using 5 frequency intervals. Although radionuclide decay is distributed according to the Poisson distribution when more than 15 to 20 counts are accumulated, the Poisson distribution can be considered to be a special case of the normal or Gaussian distribution. "

\subsection{STEAM AND ELEVATED TEMPERATURE EXPERIMENTATION}

Since the monitor had worked reasonably close to its claimed sensitivity at room temperature and humidity, we endeavored next to examine it at conditions approaching and reaching TSCA Incinerator stack conditions. If the Mylar film were breached, a catastrophic failure of the detector could occur; therefore, we proceeded cautiously. The detector cost is in the thousands of dollars.

\section{We proceeded as follows}

1. The counting time was fixed at $6 \mathrm{~min}$ because there were several days of background counting data at that rate and it seemed a fair compromise.

2. The Calrod heaters were raised in temperature in increments of about $10^{\circ} \mathrm{F}$, while the (a) inlet temperature to the monitor and (b) the pressure drop were measured. The objective was to bring the temperature to the operating point and maintain it before steam would be introduced while avoiding overshoot. The Calrod heaters were raised to final set points of 270.265 and $260^{\circ} \mathrm{F}$ (shown as $T_{c 1}, T_{c 2}$, and $T_{c 3}$ in Fig. 1) before steam was introduced. 
3. The steam flow was begun initially at low pressure, 50 psig at point $P_{s}$, and raised in increments of about 20 psig.

4. The inlet saturated air temperature to the Calrod heaters was determined at point T1.

5. A pitot tube was used to determine whether the proper flow rate of humidified air was still maintained at point $\mathrm{DPI}\left(\Delta \mathrm{P}_{1}\right)$.

6. While the steam was being introduced, large amounts of condensate initially collected were drained from the pots, as shown in Fig. 1.

7. As the adiabatic air saturation temperature rose, the temperatures of the Calrod heaters were trimmed back because of the increased enthalpy entering the system at point $T 2$. This was the most difficult part because there was always a lag in the response of the heaters and because we did not want to exceed the design value of $220^{\circ} \mathrm{F}$ of gas entering the monitor.

In this first experiment, we logged approximately $45 \mathrm{~min}$ using the steam-air mixture without any failures. The final Calrod set point was $230^{\circ} \mathrm{F}$; the pancake heater, point T3, below the filter was set at $220^{\circ} \mathrm{F}$. The pressure drop across the filter was increased from 14 to $18 \mathrm{in}$. of water, at point $\mathrm{DP} 2\left(\Delta \mathrm{P}_{2}\right)$, reaction, which we interpreted as arising from some condensation on the filter. Over the same period, the pitot measurement $\left(\Delta \mathrm{P}_{1}\right)\left(D \mathrm{P}_{1}\right)$ of flow velocity declined from 4.8 to eventually 3 in. of water. The final saturated air inlet temperature was $190^{\circ} \mathrm{F}$, and, in fact, because of this high value, we decided to terminate the run for fear of damaging the Mylar window. The final steam pressure was about $80 \mathrm{psig}$ at point $\mathrm{P}_{\mathrm{s}}$. The steam humidifier appeared to work according to design. The Mylar window and filter were inspected following the run and found to be coated with drops of moisture and the filter to be damp. Evidently, we had experienced condensation during the run and had not located the proper operating temperatures of the heaters yet. Figure 9 displays the alpha and beta counts during and following the run along with pertinent points during the operation. It can easily be observed that the alpha and beta radionuclide reading both dropped. We interpreted this result at that time as resulting from gradual water condensation. Our current interpretation, however, is that the loss of sensitivity in both channels is related instead to the rise in temperature or to both factors. The guard counter, which measures gamma-ray background, did not exhibit this effect; its counts during the same period are shown in Fig. 10. They appear altogether random and unaffected in a consistent way with the rise in temperature. The beta activity levels appear to recover their normal, or prerun, values more rapidly than the 
alpha readings following the return of the unit to ambient temperatures, as can be observed in Fig. 9. at times between 120 and $180 \mathrm{~min}$.

In the second experiment, in which we logged about 4 hours with steam, it appeared that a drop in alpha sensitivity of the proportional detector was occurring as the temperature was raised independent of the steam flow. There is, of course, some considerable statistical variation in the data, but it appeared that the alpha activity dropped about $75 \%$ within the first hour of operation, as the temperature was raised from ambient to $187^{\circ} \mathrm{F}$. Very little change was seen in the pressure drop across the filter during this time. When the steam was started, the sensitivity of alpha detection dropped to a flat zero, which we interpreted as evidence of severe water condensation on the Mylar film. Further evidence of the condensation was the large rise in the pressure drop across the filter. It increased to 45 in. of water from its normal 18 in. In addition, the flow velocity, as measured by the pitot tube pressure difference $\left(\mathrm{DP}_{2}\right)\left(\Delta \mathrm{P}_{2}\right)$, which was an indication of the flow rate of the saturated air, dropped to $0.25 \mathrm{in}$. of water, and some condensed steam began rising from the air inlet of the steam cart. The steam flow was cut back and the temperature was raised in an effort to dry the monitor chamber and regain an alpha radiation signal. This effort was successful, as indicated at time $5 \mathrm{~h}$ in Fig. 11, at which time the alpha detection began to recover. The pressure drop across the filter diminished, and the pitot-tube velocity began to rise again to its expected values. A second run was begun on steam, and condensation again occurred with similar results in the alpha activity readings. Curiously, in this experiment, the beta activity rose sharply at nearly the exact point at which the alpha activity decayed to zero. This phenomenon was not observed in the first experiment when the two channels both dropped to very low readings. There is yet no explanation for this anomaly. An examination of the gamma guard counter, physically located above the alpha and beta detectors, reveals no clear pattern because of the large scatter in the gamma counts. It appears that, usually, there is a slight drop in the gamma sensitivity as well, though not so pronounced as with the first two channels.

Samples of moisture-laden air were taken per U.S. Environmental Protection Agency (EPA) Method 4 at $182^{\circ} \mathrm{F}$ at the entrance to the monitor to verify that the humidification apparatus was performing to specification. Approximately $61 \mathrm{wt} \%$ moisture was found in the sample. This corresponds to a saturation or dew point of about $193^{\circ} \mathrm{F}$, so that the sample air is safely saturated (i.e., it represents a worse case of TSCA Incinerator stack gas, which would not be supersaturated unless there were entrainment of condensed moisture). 


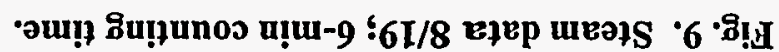

səznu!̣u

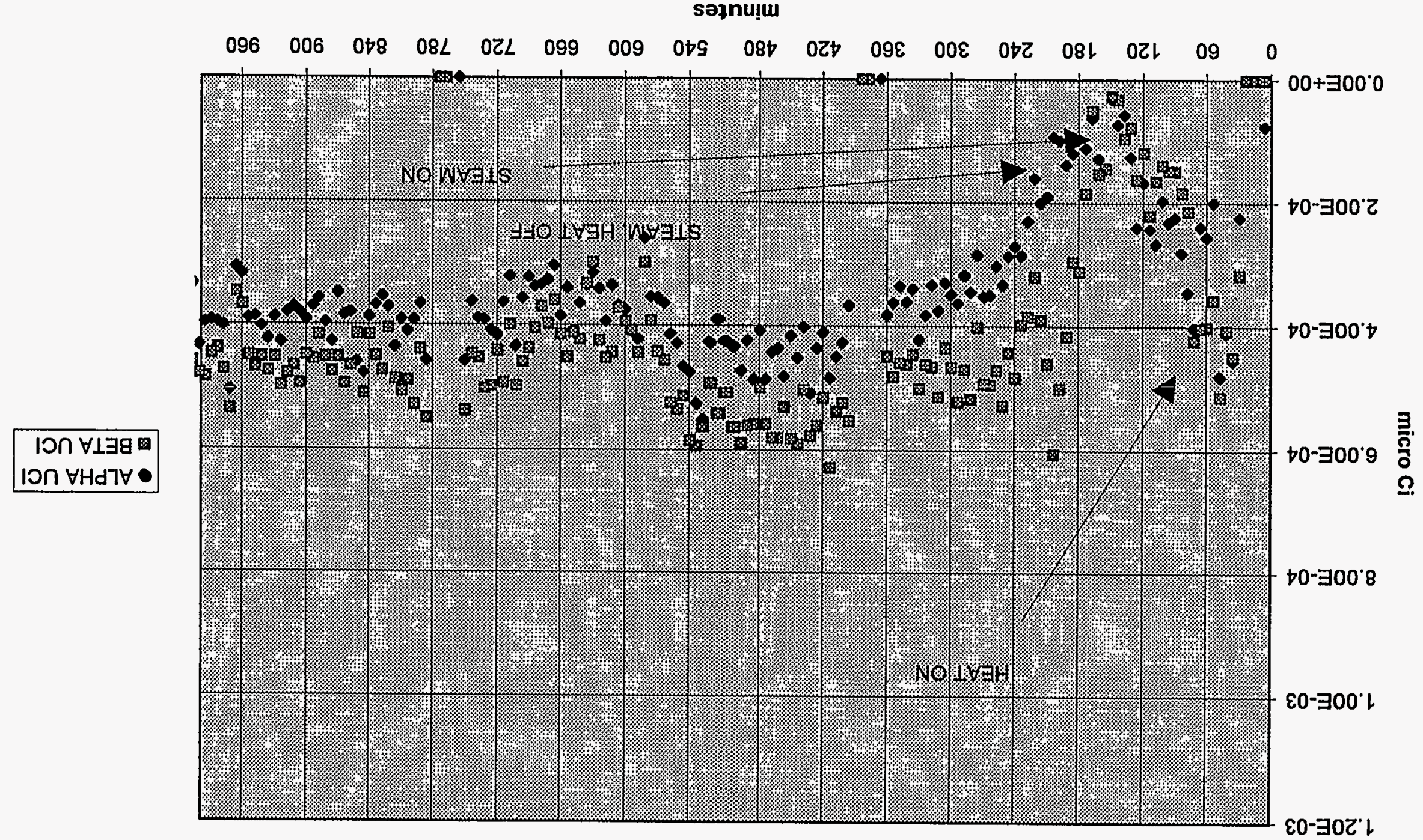

LEڤb-86 OMA TNYO 


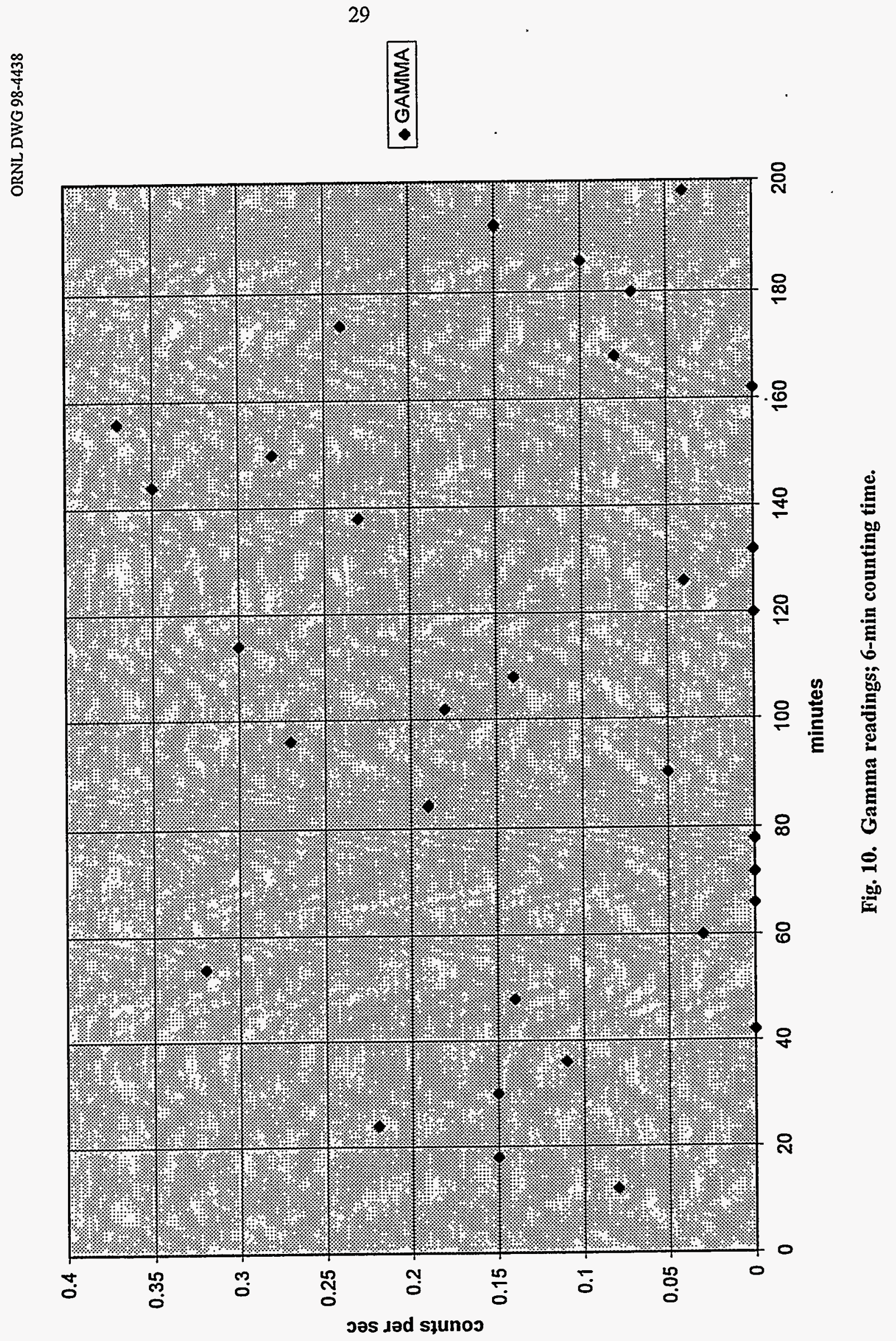




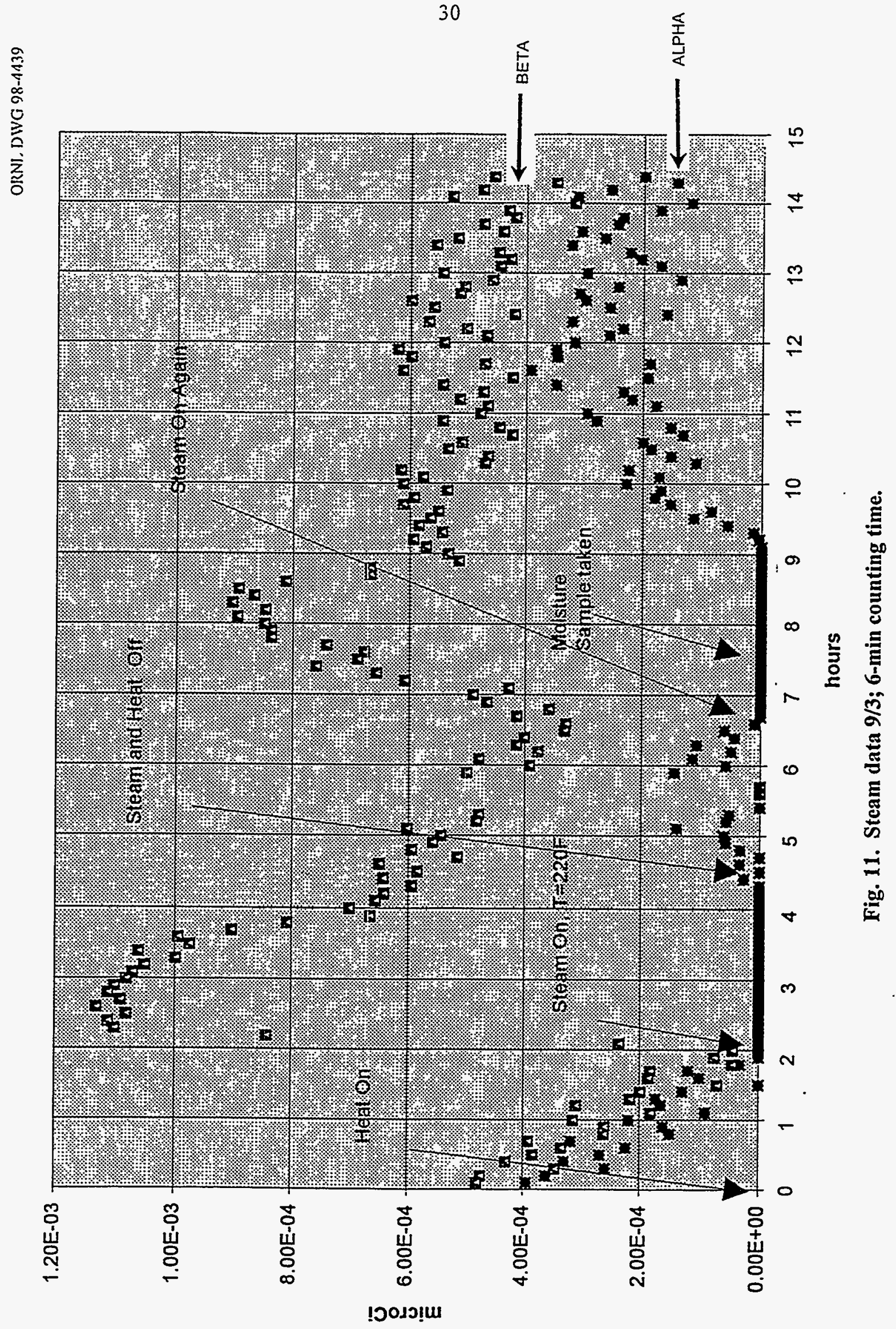


In the third steam experiment, our first objective was the elimination of condensation from the system because, once condensed, water is difficult to remove, and it is certain to affect the alpha sensitivity. The alpha and beta activity during this run and the pertinent points during the data collection are shown in Fig. 12. In this instance, the heat was first introduced using the Calrod heaters at time $0 \mathrm{~min}$, and no steam was added until time $70 \mathrm{~min}$. The drops in the sensitivity of the alpha and beta detectors are quite evident in the absence of steam in this case. When steam was introduced, it was allowed in slowly enough such that no increase in pressure drop across the filter was apparent at all; it remained at 18 in. of water. That is a good indication of an absence of condensation on the filter; however, the conclusion is further reinforced by the temperature at point $\mathrm{T} 3$, below the filter. The pancake heater was not used in this experiment, and the temperature controller thermocouple, which normally read the pancake temperature itself, now became an indication of the actual gas temperature. The temperature remained in excess of $200^{\circ} \mathrm{F}$. while the maximum adiabatic saturation temperature never rose above $183^{\circ} \mathrm{F}$. Because the pancake heater thermocouple is downstream of the filter and Mylar film and there is no heater between the two, the actual temperature of the filter must be in excess of the pancake thermocouple temperature reading. Hence, there could be no condensation at that point. It is still possible that the Mylar film temperature may have been lower than the filter temperature, so the possibility of moisture condensation on the film is not excluded. The activity data, however, are qualitatively different than those during the second run in which the activity fell to a solid zero and remained there during the period of suspected condensation.

\subsection{DISCUSSION OF RADIONUCLIDE SENSITIVITY LOSS}

According to B. Rossi and H. Staub, ${ }^{12}$ the proportional multiplication factor increases at a given voltage as the pressure of the gas is reduced. The reason is that the mean free path of the electrons is increased at lower pressure and that the electrical field, therefore, has more time in which to accelerate the electrons between collisions with the gas molecules. The thermal motion of the gas molecules is insignificant by comparison. No specific mention, however, is made of temperature effects. Two later papers appear in the literature which address the effects of axial and radial temperature gradients on proportional counters. C. W. McCutchen found that an increase in temperature, at constant pressure, can cause a slight loss in energy resolution of the 


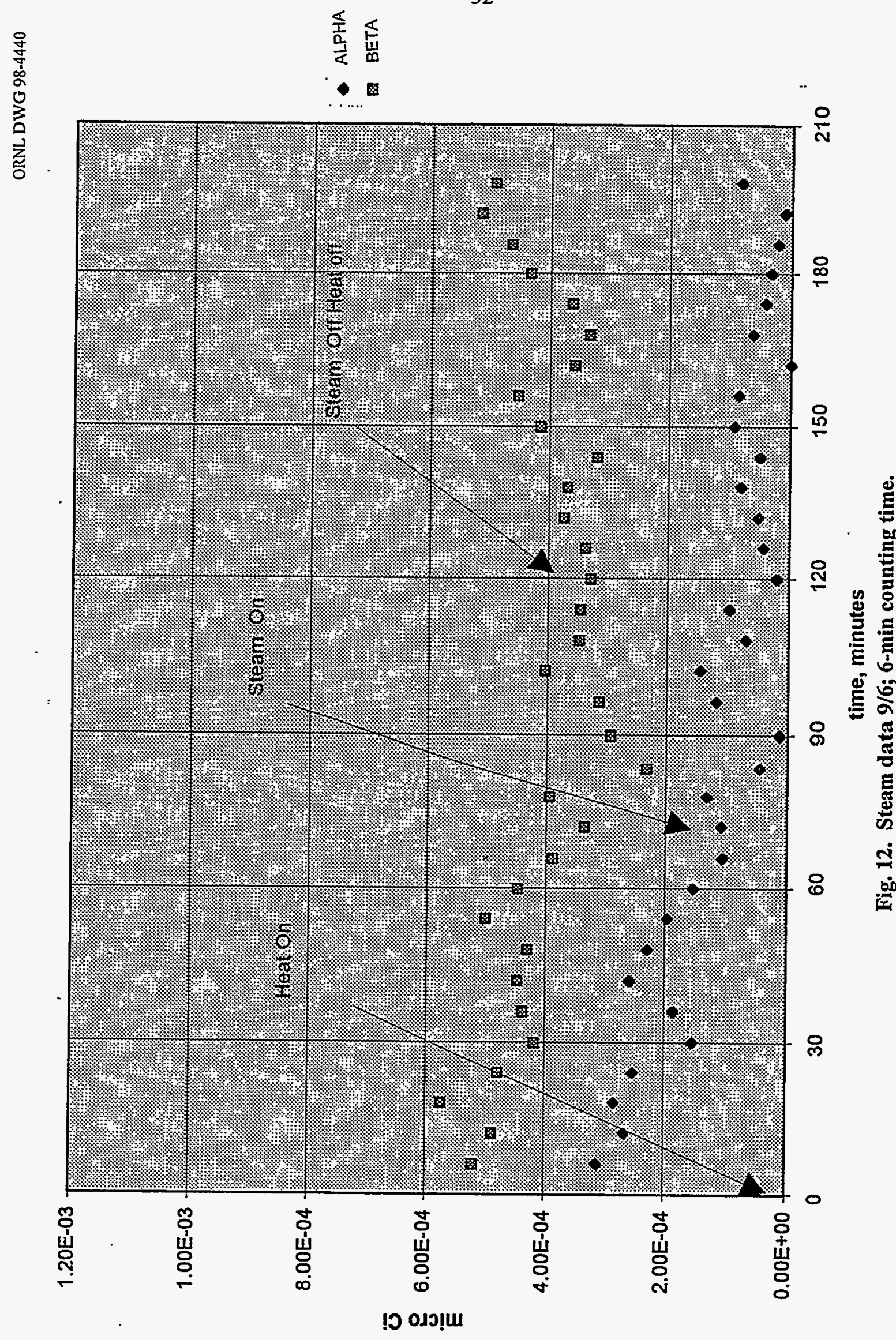


counter, but otherwise no other ill effects. ${ }^{13}$ T. Nagatani and Y. Sakaki found that through the use of a radial temperature gradient, they could increase the gas multiplication factor because of the lowering of the gas density in the region of higher temperature. ${ }^{14}$ Communications with the manufacturers of the instrument have confirmed their success in recording data within their own confidence intervals at temperatures to $70^{\circ} \mathrm{C}, 158^{\circ} \mathrm{F}$. They experienced instabilities in their readings at temperatures in excess of these. For some reason, the instabilities first appeared in the guard detector and later were encountered in the alpha and beta detectors. ${ }^{15}$ We have been unable to reliably generate stable data even at temperatures below $150^{\circ} \mathrm{F}$. The hypothesis is that it is not the temperature itself which is causing our problem, but some problem which arises as a result of the elevated temperature, such as a permeation of air through the Mylar film or a leak, both of which could cause a complete, but recoverable, loss in detection efficiency.

\section{CONCLUSIONS}

One apparatus was successfully developed to generate water-saturated air at $183^{\circ} \mathrm{F}$ to simulate TSCA Incinerator stack gas at flow rates of $25 \mathrm{scfm}$ for the purpose of laboratory testing of an EG\&G Berthold LB-150 alpha, beta particulate radionuclide monitor. A second apparatus was designed and built which successfully heats the saturated air stream generated in the first apparatus to a temperature at which condensation in the monitor can be prevented. Radionuclide data were collected with the monitor at ambient temperature and pressure. The claimed sensitivities of the monitor were essentially confirmed, and a reasonable counting time was chosen with thorium sources. Once these objectives were accomplished, it was learned that the monitor loses perhaps $75 \%$ of its sensitivity when the temperature is elevated from ambient to $220^{\circ} \mathrm{F}$. This loss is not related to condensation of moisture in the monitor chamber or filter, and it occurs in the absence of steam. Further investigation is recommended before installation into the radiologically contaminated environment of the TSCA Incinerator stack. Several possible approaches to the problem are under consideration, including: (1) use of a solid-state detector more impervious to the conditions of the stack gas, (2) implementation of a less permeable Mylar or film of other material, and (3) modifications or repairs to the current instrument. We are in contact with the manufacturer in Germany to address these problems. 


\section{REFERENCES}

1. J. T. Shor, S. P. N. Singh, and L. V. Gibson, Jr., Oak Ridge National Laboratory, Oak Ridge, Tenn., informal memorandum to D. Hutchins, U.S. Department of Energy, Oak Ridge Operations, Oak Ridge, Tenn., "Test Plan for the Development and Demonstration of an EG\&G Berthold Continuous Radionuclide Emissions Monitor at the K-25 TSCA Incinerator," February 1997.

2. DuPont Company, "DuPont Packaging: Mylar MC2,"Wilmington, Delaware, 1997.

3. D. G. Miller, Radioactivity and Radiation Detection, Gordon and Breach, New York, 1972.

4. W. L. McCabe, J. C. Smith, and P. Harriot, Unit Operations of Chemical Engineering, McGraw-Hill, New York, 1985.

5. W. Davis, The University of Tennessee, Knoxville, Tenn., personal communication to J. T. Shor, Oak Ridge National Laboratory, Oak Ridge, Tenn., October 1996.

6. R. Perry and D. Green, pp. 29-92 in Chemical Engineer's Handbook, McGraw-Hill, New York, 1984.

7. J. R. Distefano, Oak Ridge National Laboratory, Oak Ridge, Tenn., personal communication to J. T. Shor, Oak Ridge National Laboratory, Oak Ridge, Tenn., May 16, 1997.

8. P. Chiaro, Oak Ridge National Laboratory, Oak Ridge, Tenn., personal communication to J. T. Shor, Oak Ridge National Laboratory, Oak Ridge, Tenn., Feb. 23, 1997.

9. J. Lassater, EG\&G Berthold, Oak Ridge, Tenn., personal communication to J. T. Shor, Oak Ridge National Laboratory, Oak Ridge, Tenn., June 3, 1997.

10. W. J. Price, p. 61 in Nuclear Radiation Detection, McGraw-Hill, New York, 1964.

11. D. G. Miller, Radioactivity and Radiation Detection, Gordon and Breach, New York, 1972.

12. B. Rossi and H. Staub, p. 76 in Ionization Chambers and Counters, Experimental Techniques, McGraw-Hill, New York, 1949.

13. C. W. McCutchen, "Thermal Gradient Effect in Proportional Counters," Rev. Sci. Instrum., 27, 106 (1956).

14. T. Nagatani and Y. Sakaki, "Increase of Pulse Height in a Proportional Counter by Means of a Radial Thermal Gradient," Rev. Sci. Instrum., 34, 556 (1962).

15. W. Reuter, EG\&G Berthold, Wildbad, Germany, personal communication to J. T. Shor, Oak Ridge National Laboratory, Oak Ridge, Tenn., Aug. 20, 1997. 
Appendix A. SAMPLE HUMIDIFICATION CALCULATIONS FOR AIR IN AT $78^{\circ} \mathrm{F}$, SATURATED WATER OUT AT $190^{\circ} \mathrm{F}$, AND SATURATED AIR OUT AT $190^{\circ} \mathrm{F}$ 


$$
\mathrm{A}=\left(\begin{array}{ccc}
1 & 1 & -1 \\
1193 & 38.8 & 158 \\
1 & 0.02 & 1
\end{array}\right) \quad \begin{aligned}
& \text { total mass } \\
& \text { enthalpy } \\
& \mathrm{H}_{2} \mathrm{O} \text { balance }
\end{aligned}
$$

$A$ is the matrix of coefficients of the combined total mass, heat, and water mass balances.

$$
\begin{aligned}
& \mathrm{zx}=65.2 \\
& \mathrm{zx} \text { is mass of humid air } \quad \mathrm{b}=\left(\begin{array}{c}
\mathrm{zx} \\
\mathrm{zx} \times 620 \\
\mathrm{zx} \times 0.52
\end{array}\right)
\end{aligned}
$$

Matrix $B$ represents the total mass, enthalpy, and total water in the exit stream, fixed as by design.

$$
x=A^{-1} \times b
$$

Matrix $x$ is the inlet steam, inlet air, and outlet water condensate that will be needed and generated at design conditions.

$$
\begin{aligned}
& \mathrm{x}=\left(\begin{array}{c}
32.747 \\
32.952 \\
0.498
\end{array}\right) \quad \begin{array}{l}
\text { steam } \\
\text { air } \\
\text { water }
\end{array} \\
& \mathrm{T}=360^{\circ} \mathrm{F}, 150 \mathrm{lb} \text { steam in } \\
& \mathrm{K}=361 \\
& \mathrm{~F}=(\mathrm{K}-273) \times 1.8+32 \\
& \mathrm{~F}=190.4
\end{aligned}
$$




$$
\begin{aligned}
& \rho=\frac{1}{361 \times 0.0821} \\
& \rho=0.034 \mathrm{~mol} / \mathrm{L}
\end{aligned}
$$

$$
\begin{aligned}
& \text { mass }=\rho \times[28.8 \times(1-0.637)+18 \times 0.637] \times \frac{40000}{454} \\
& \text { mass }=65.163 \mathrm{lb} \text { gas } / \mathrm{h} \quad\left(40 \mathrm{~m}^{3} / \mathrm{h}, \text { gas at stack conditions }\right)
\end{aligned}
$$

$$
\begin{aligned}
& \text { wt } \% \mathrm{H}_{2} \mathrm{O}=\frac{1.099}{2.099}=0.524 \\
& \text { wt } \% \mathrm{H}_{2} \mathrm{O}=\text { wh }
\end{aligned}
$$

wh is defined as the weight percent water

$$
\begin{aligned}
& \mathrm{mol} \% \mathrm{H}_{2} \mathrm{O}=\frac{\frac{w h}{18}}{\frac{w h}{18}+\frac{1-w h}{28.8}} \\
& \mathrm{~mol} \mathrm{\%} \mathrm{H}_{2} \mathrm{O}=0.637
\end{aligned}
$$


Appendix B. HEAT EXCHANGER DESIGN CALCULATIONS 
The working equation for Nusselt number is

$$
\mathrm{Nu}(\mathrm{d})=0.023 \mathrm{Nre}(\mathrm{d})^{0.8} \cdot \mathrm{Npr}^{\frac{1}{3}},
$$

where

$$
\begin{aligned}
& \mathrm{Nu}(\mathrm{d})=\text { Nusselt number }=\mathrm{h} \times \mathrm{d} / \mathrm{k}, \\
& \mathrm{Nre}(\mathrm{d})=\text { Reynolds number }=\mathrm{d} \times \mathrm{G} / \mu, \\
& \mathrm{Npr} \quad=\text { Prandtl number }=\mathrm{cp} \times \mu / \mathrm{k}, \\
& \mathrm{h} \quad=\text { heat transfer coefficient, } \\
& \mathrm{d} \quad=\text { diameter } \\
& \mathrm{k} \quad=\text { thermal conductivity, } \\
& \mathrm{G} \quad=\text { mass velocity, } \\
& \mu \quad=\text { viscosity, and } \\
& \mathrm{cp} \quad=\text { specific heat. }
\end{aligned}
$$

Fluid properties, except specific heat, are evaluated at the average film temperature, whereas specific heat is evaluated at the bulk or mean temperature.

$$
T_{f}=\left(T_{s}+T_{b}\right) / 2
$$

where

$$
\begin{aligned}
& \mathrm{T}_{\mathrm{f}} \quad=\text { film temperature, } \\
& \mathrm{T}_{\mathrm{s}} \quad=\text { surface temperature, and } \\
& \mathrm{T}_{\mathrm{b}} \quad=\text { bulk temperature. }
\end{aligned}
$$

$$
T_{b}=\left(T_{i}+T_{0}\right) / 2,
$$

where

$\mathrm{T}_{\mathrm{i}} \quad=$ inlet temperature and

$\mathrm{T}_{\mathrm{o}}=$ outlet temperature . 
Design basis from Appendix A is $40 \mathrm{~m}^{3} / \mathrm{h}$ of air saturated with steam at $190^{\circ} \mathrm{F}$ to be heated at $200^{\circ} \mathrm{F}$.

The corresponding flow rate of dry air at standard conditions $\left(68^{\circ} \mathrm{F}, 29.92 \mathrm{in} . \mathrm{Hg}\right)$ is

$$
40 \mathrm{~m}^{3} / \mathrm{h} \times 35.315 \mathrm{ft}^{3} / \mathrm{m}^{3} \times 1 \text { hour } / 60 \mathrm{~min} \times(1-0.636) \times 527.67 / 649.67=6.97 \mathrm{ft}^{3} / \mathrm{min}
$$

Design parameters which can be varied include the tube diameter, heated length, and surface temperature. The required heat balance and appropriate heat transfer relationship must be simultaneously satisfied.

$$
Q=h \times A \times\left(T_{s}-T_{b}\right)=m \times c p \times\left(T_{0}-T_{i}\right)
$$

where

Q = heat transfer,

A = surface area, and

$\mathrm{m} \quad$ mass.

A spreadsheet was developed to facilitate simultaneous solution of the equations, including evaluation of fluid properties. The final design was a tube having an internal diameter of 1.370 inches and a $4-\mathrm{ft}$ heated length. A surface temperature requirement of $267^{\circ} \mathrm{F}$ was calculated.

$\begin{array}{ll}\text { Flow } & 6.96 \mathrm{dscfm} \\ \text { Barometer } & 29.92 \mathrm{in.} \mathrm{Hg} \\ \text { Static } & 0 \text { in. } \mathrm{H}_{2} \mathrm{O} \\ \text { ID } & 1.37 \mathrm{in} \\ \text { Internal cross-sectional area } & 0.010237 \mathrm{ft}^{2} \\ \text { Length } & 48 \mathrm{in} \\ \text { Surface area } & 1.43 \mathrm{ft}^{2} \\ \mathrm{~N}_{2} & 79.1 \mathrm{dry} \mathrm{mol} \% \\ \mathrm{O}_{2} & 20.9 \mathrm{dry} \mathrm{mol} \mathrm{\%} \\ \mathrm{H}_{2} \mathrm{O} \text { saturated } & 63.56 \mathrm{~mol} \%\end{array}$


B-3

$\begin{array}{ll}\mathrm{H}_{2} \mathrm{O} \text { condensed } & 63.56 \mathrm{~mol} \% \\ \mathrm{CO}_{2} & 0 \text { dry mol \% } \\ \mathrm{T}_{\mathrm{i}} & 190^{\circ} \mathrm{F} \\ \mathrm{T}_{\mathrm{s}} & 267^{\circ} \mathrm{F} \\ \mathrm{T}_{\mathrm{o}} & 220^{\circ} \mathrm{F} \\ \mathrm{T}_{\mathrm{b}} & 205^{\circ} \mathrm{F} \\ \mathrm{T}_{\mathrm{f}} & 236^{\circ} \mathrm{F} \\ \mathrm{Hv} @ \mathrm{~T}_{\mathrm{i}} & 996.1 \mathrm{Btu} / \mathrm{lb}\end{array}$

$\begin{array}{lcccc} & \underline{\mathrm{lb} / \text { hour }} & \underline{\mathrm{lb} \text { mol/hour }} & \underline{\mathrm{Q} \text { Btu/hour }} & \text { Q kW } \\ \mathrm{N}_{2} & 24.0 & 0.858 & 179.5 & \\ \mathrm{O}_{2} & 7.25 & 0.226 & 48.66 & \\ \mathrm{H}_{2} \mathrm{O}(\mathrm{g}) & 34.09 & 1.892 & 463.8 & \\ \mathrm{H}_{2} \mathrm{O}(\mathrm{L}) & 0 & 0 & 0 & \\ \mathrm{CO}_{2} & 0 & 0 & 0 & \\ \mathrm{Sum} & 65.3 & 2.97 & 692.0 & 0.202829\end{array}$

h required 7.780774 Btu/(hour $\mathrm{ft}^{2}{ }^{\circ} \mathrm{F}$ )

$\begin{array}{ll}\mathrm{N}_{\text {Re }} & 17702 \\ \mathrm{~N}_{\mathrm{Pr}} & 0.903591 . \\ \mathrm{N}_{\text {calc }} & 55.65 \\ \text { h calculated } & 7.8405 \mathrm{Btu} / \text { hour } \mathrm{ft}^{2}{ }^{\circ} \mathrm{F}\end{array}$




\section{B-4}

Specific heat capacity

$\mathrm{kBtu} /\left(\mathrm{lb}^{\circ} \mathrm{F}\right)$

$\begin{array}{llll} & \text { mass frac } & \underline{T}_{b} & \underline{c p @, T_{b}} \\ \mathrm{~N}_{2} & 0.367 & 369 & 0.249 \\ \mathrm{O}_{2} & 0.110 & 369 & 0.223 \\ \mathrm{H}_{2} \mathrm{O} & 0.521 & 369 & 0.453 \\ \mathrm{CO}_{2} & 0 & 369 & 0.217 \\ \mathrm{Mix} & 1 & & 0.352812\end{array}$

Gas viscosity $\left(M_{i}=\right.$ molecular weight $)$

\begin{tabular}{|c|c|c|c|c|c|}
\hline & $\underline{y}_{i}$ & $\mathrm{y}_{\mathrm{i}} \times \mathrm{Mi}^{1 / 3}$ & $\underline{T}_{f}$ & $\mu$ (micropoise) & $\underline{\mu}, \mathrm{lb} /(\mathrm{ft} \mathrm{s})$ \\
\hline $\mathrm{N}_{2}$ & 0.288 & 1.525 & 386 & 216.5 & 0.000015 \\
\hline $\mathrm{O}_{2}$ & 0.076 & 0.430 & 386 & 250.5 & 0.000017 \\
\hline $\mathrm{H}_{2} \mathrm{O}$ & 0.635 & 2.697 & 386 & 131.3 & $8.8 E-06$ \\
\hline $\mathrm{CO}_{2}$ & 0 & 0 & 386 & 192.8 & 0.000013 \\
\hline Mix & 1 & 4.65 & & 170.2 & 0.000011 \\
\hline
\end{tabular}

Gas thermal conductivity ( $\mathrm{Mi}=$ molecular weight $)$

\begin{tabular}{lllccc} 
& \multicolumn{1}{c}{$\underline{\mathrm{y}}_{i}$} & $\underline{\mathrm{y}}_{\mathrm{i}} \times \mathrm{M}_{i}^{1 / 3}$ & $\underline{\mathrm{T}}_{\mathrm{f}}$ & $\underline{\mathrm{K}(\mathrm{W} / \mathrm{mK})}$ & $\underline{\mathrm{Btu} /\left(\mathrm{h} / \mathrm{ft}^{\circ} \mathrm{F}\right)}$ \\
$\mathrm{N}_{2}$ & 0.288 & 0.875 & 386 & 0.0316 & 0.0182 \\
$\mathrm{O}_{2}$ & 0.076 & 0.241 & 386 & 0.0331 & 0.0191 \\
$\mathrm{H}_{2} \mathrm{O}$ & 0.635 & 1.666 & 386 & 0.0250 & 0.0144 \\
$\mathrm{CO}_{2}$ & 0 & 0 & 386 & 0.0239 & 0.0138 \\
$\mathrm{Mix}$ & 1 & 2.783 & & 0.0278 & 0.0160
\end{tabular}




\section{B-5}

The following table illustrates the effect of tube diameter on heat transfer coefficient and required surface temperature for nominal tubing sizes that were available commercially, at a constant mass flow rate.

\begin{tabular}{|l|c|c|c|}
\hline \multicolumn{3}{|c|}{ TABLE B.1. Tube diameter and heat transfer coefficient } \\
\hline \multicolumn{2}{|c|}{ Tube diameter in inches } & $\begin{array}{c}\text { h } \\
\left.\text { Btu/(hour } \mathrm{ft}^{2}{ }^{\circ} \mathrm{F}\right)\end{array}$ & $\mathrm{T}_{\text {s }}$ \\
\hline OD & $\mathrm{ID}$ & 32.0 & 239 \\
\hline 0.75 & 0.625 & 17.7 & 248 \\
\hline 1 & 0.870 & 7.8 & 267 \\
\hline 1.5 & 1.370 & 4.5 & 284 \\
\hline 2 & 1.870 & 2.9 & 300 \\
\hline 2.5 & 2.370 & & \\
\hline
\end{tabular}


Appendix C. PLATEAU VOLTAGE DATA 


\section{C-1}

Detector - Plateau

\section{BERTHOLD LB5310}

User File Name: ALPHA/BETA

Comment: SR-90

Meas. time (mm:ss): 0:18
Device Id: 0001

Date/Time: 21/05/97 12:40:51

Preset time (mm:ss): 0:18

\begin{tabular}{lccr}
$\begin{array}{c}\text { HV } \\
(\mathrm{V})\end{array}$ & $\begin{array}{c}\mathrm{A} \\
(\mathrm{cpm})\end{array}$ & $\begin{array}{c}\mathrm{B} \\
(\mathrm{cpm})\end{array}$ & $\begin{array}{c}\mathrm{C} \\
(\mathrm{cpm})\end{array}$ \\
\hline 1400.00 & 1823.33 & 5143.33 & 23.33 \\
1490.00 & 17603.33 & 17710.00 & 43.33 \\
1580.00 & 48696.67 & 39386.67 & 96.67 \\
1670.0 & 102820.00 & 71426.66 & 210.00 \\
1760.00 & 163536.67 & 100693.34 & 240.00 \\
1850.00 & 196963.33 & 117246.66 & 256.67 \\
1940.00 & 214836.67 & 117246.66 & 310.00 \\
2030.00 & 227393.33 & 122390.00 & 303.33 \\
2120.00 & 232990.00 & 123573.34 & 406.67 \\
2210.00 & 239746.67 & 126663.34 & 233.33 \\
2300.00 & 243366.67 & 127990.00 & 260.00 \\
2390.00 & 247733.33 & 132300.00 & 430.00
\end{tabular}

ORNL DWG 98-4441

mpn

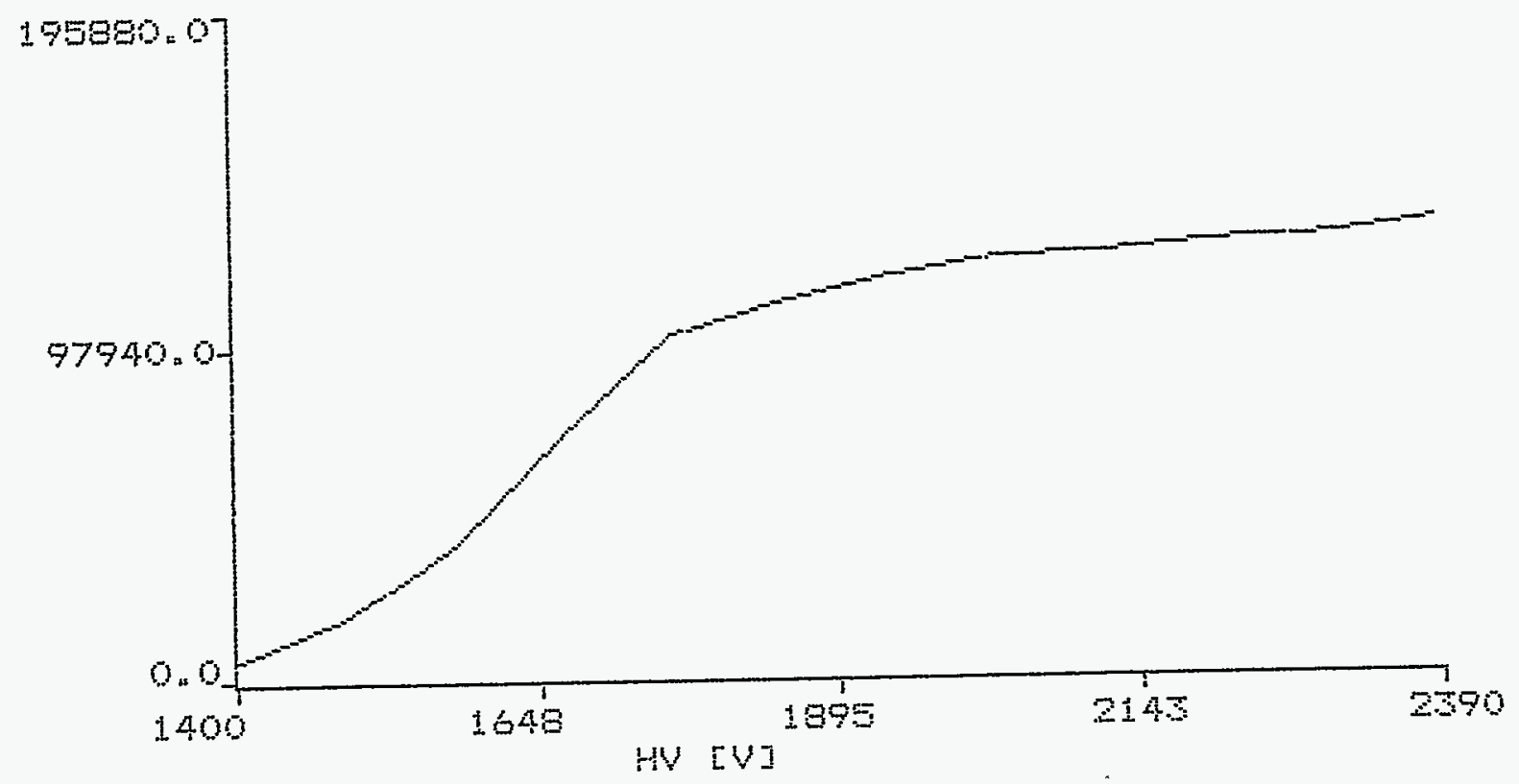

Fig. C.1. Beta plateau voltages. 


\section{C-2}

Detector - Plateau

-............

BERTHOLD LB5310

User File Name: ALPHA/BETA

Device Id: 0001

Comment: PU-238

Date/Time: 21/05/97 12:30:39

Meas. time (mm:ss): 0:18

Preset time (mm:ss): 0:18

\begin{tabular}{rccr}
$\begin{array}{c}\text { HV } \\
\text { (V) }\end{array}$ & $\begin{array}{c}\mathrm{A} \\
(\mathrm{cpm})\end{array}$ & $\begin{array}{c}\mathrm{B} \\
(\mathrm{cpm})\end{array}$ & $\begin{array}{r}\mathrm{C} \\
(\mathrm{cpm})\end{array}$ \\
\hline 700.00 & 14603.33 & 0.00 & 0.00 \\
799.00 & 38590.00 & 0.00 & 0.00 \\
898.00 & 49430.00 & 0.00 & 0.00 \\
997.00 & 54810.00 & 0.00 & 0.00 \\
1096.00 & 58540.00 & 0.00 & 0.00 \\
1195.00 & 60160.00 & 0.00 & 0.00 \\
1294.00 & 63350.00 & 3.33 & 0.00 \\
1393.00 & 65310.00 & 10.00 & 6.67 \\
1492.00 & 65426.67 & 13.33 & 30.00 \\
1591.00 & 66173.34 & 266.67 & 93.33 \\
1690.00 & 68140.00 & 406.67 & 240.00 \\
1789.00 & 69990.00 & 573.33 & 260.00
\end{tabular}

ORNL DWG 98-4442

cpm

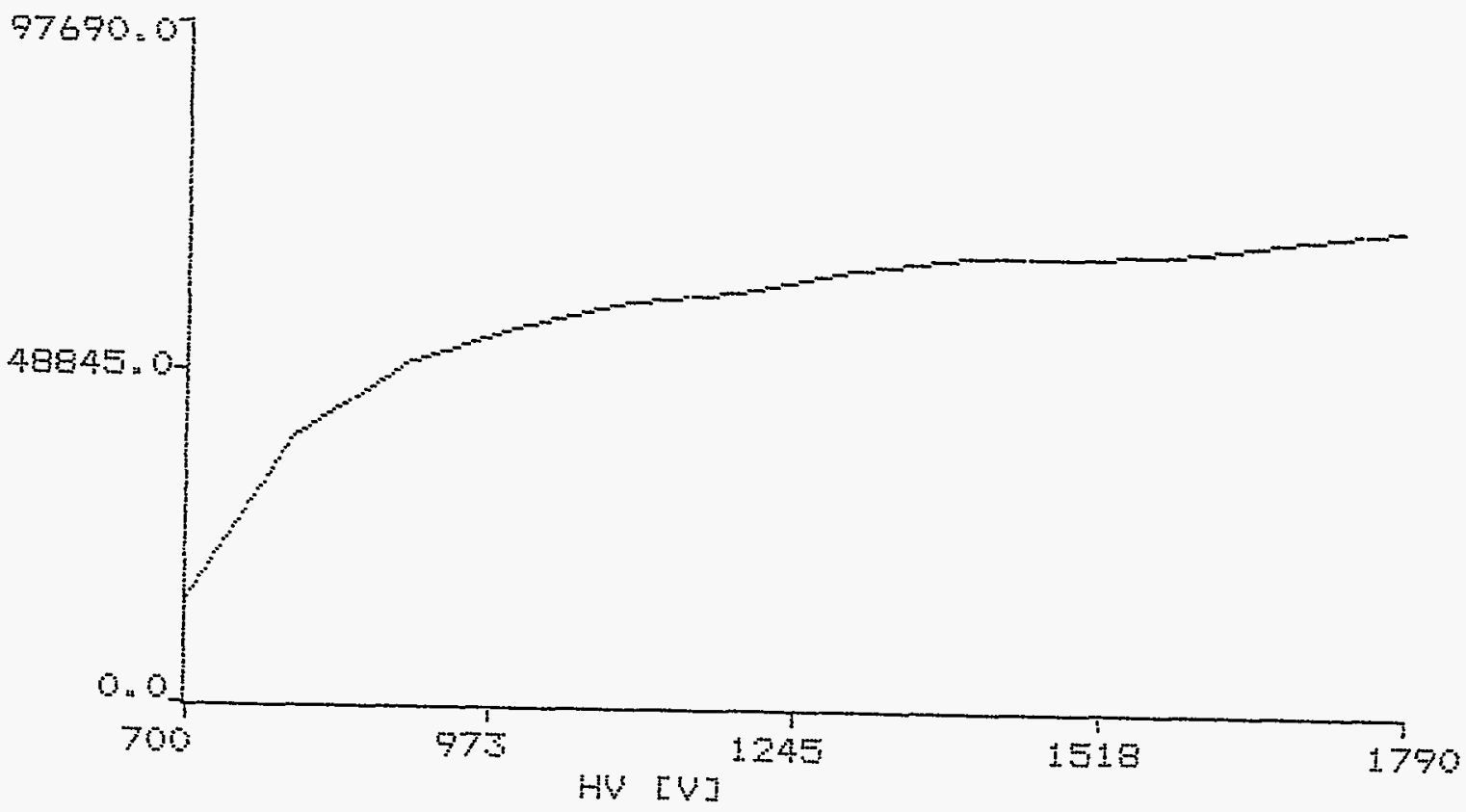

Fig. C. 2. Alpha plateau voltages. 
Appendix D. PSEUDOCOINCIDENCE DATA 
D-1

User File Name: ALPHA/BETA

Comment: Natural Background

Meas. time (mm:ss): 60:00:00
Device Id: 0001

Date/Time: 15/08/97 17:29:53

Preset time (mm:ss): 60:00:00

\begin{tabular}{cccccc}
$\begin{array}{c}\text { Meas. No. } \\
\text { (cps) }\end{array}$ & $\begin{array}{c}\text { Alpha } \\
\text { (cps) }\end{array}$ & $\begin{array}{c}\text { Beta } \\
\text { (cps) }\end{array}$ & $\begin{array}{c}\text { Pseudo } \\
\text { (cps) }\end{array}$ & $\begin{array}{c}\text { Random } \\
\text { (cps) }\end{array}$ & Guard \\
\hline 1 & 4.73 & 9.09 & 1.98 & 0.01 & 4.84 \\
2 & 9.88 & 18.29 & 4.25 & 0.04 & 4.85 \\
3 & 13.3 & 23.96 & 5.76 & 0.07 & 4.93 \\
4 & 16.51 & 29.86 & 6.96 & 0.09 & 4.89 \\
5 & 19.64 & 35.34 & 8.18 & 0.14 & 4.93 \\
6 & 27.8 & 50.47 & 11.5 & 0.29 & 4.92 \\
7 & 41.84 & 75.17 & 17.5 & 0.6 & 5.07 \\
8 & 46.26 & 82.63 & 19.44 & 0.7 & 5 \\
9 & 51.27 & 91.49 & 21.35 & 0.89 & 5.11 \\
10 & 53.72 & 96.03 & 22.35 & 0.98 & 5.12 \\
11 & 69.43 & 123.87 & 28.44 & 1.59 & 5.13 \\
12 & 81.71 & 145.59 & 33.74 & 2.27 & 5.34 \\
13 & 89.32 & 159.23 & 36.8 & 2.66 & 5.28 \\
14 & 94.91 & 168.88 & 38.75 & 3.03 & 5.27 \\
15 & 101.25 & 180.18 & 41.46 & 3.42 & 5.37 \\
16 & 110.21 & 195.84 & 44.56 & 4.08 & 5.46 \\
17 & 11.26 & 197.62 & 45.78 & 4.11 & 5.44 \\
18 & 87.46 & 154.27 & 36.38 & 2.55 & 5.3 \\
19 & 62.84 & 111.17 & 26.22 & 1.3 & 5.1 \\
20 & 43.95 & 78.16 & 18.4 & 0.67 & 5 \\
21 & 31.73 & 57.4 & 13.3 & 0.35 & 4.96 \\
22 & 26.5 & 48.6 & 11.09 & 0.24 & 4.89 \\
23 & 23.1 & 42.77 & 9.55 & 0.19 & 4.94 \\
24 & 20.44 & 37.77 & 8.58 & 0.15 & 4.88 \\
25 & 18.13 & 33.59 & 7.62 & 0.12 & 4.84 \\
26 & 16.57 & 31.13 & 6.95 & 0.1 & 4.92 \\
27 & 16.03 & 30.04 & 6.71 & 0.09 & 4.86 \\
28 & 17.37 & 32.27 & 7.22 & 0.1 & 4.87 \\
29 & 21.46 & 39.95 & 8.7 & 0.17 & 4.89 \\
30 & 27.95 & 51.76 & 11.46 & 0.26 & 4.94 \\
31 & 36.07 & 66.48 & 14.54 & 0.48 & 5.04 \\
32 & 43.59 & 80.09 & 17.61 & 0.66 & 4.97 \\
33 & 52.01 & 95.83 & 20.87 & 0.97 & 5.03 \\
34 & 61 & 112.48 & 24.34 & 1.3 & 5.06 \\
35 & 81.62 & 150.35 & 32.33 & 2.3 & 5.28 \\
36 & 90.6 & 166.03 & 36.07 & 2.78 & 5.31 \\
37 & 95.31 & 174.66 & 37.84 & 3.12 & 5.35 \\
38 & 103.95 & 190.47 & 41.05 & 3.77 & 5.43
\end{tabular}


D-2

\begin{tabular}{cccccc}
$\begin{array}{c}\text { Meas. No. } \\
\text { (cps) }\end{array}$ & $\begin{array}{c}\text { Alpha } \\
\text { (cps) }\end{array}$ & $\begin{array}{c}\text { Beta } \\
\text { (cps) }\end{array}$ & $\begin{array}{c}\text { Pseudo } \\
\text { (cps) }\end{array}$ & $\begin{array}{c}\text { Random } \\
\text { (cps) }\end{array}$ & Guard \\
\hline 39 & 115.47 & 211.34 & 45.77 & 4.53 & 5.49 \\
40 & 117.2 & 214 & 46.35 & 4.67 & 5.41 \\
41 & 112.79 & 205.02 & 44.95 & 4.35 & 5.45 \\
42 & 87.54 & 158.44 & 35.55 & 2.63 & 5.33 \\
43 & 61.82 & 111.93 & 25.56 & 1.32 & 5.15 \\
44 & 40.84 & 74.01 & 17.01 & 0.59 & 4.98 \\
45 & 30.7 & 56.49 & 12.95 & 0.33 & 5.02 \\
46 & 25.89 & 47.96 & 10.85 & 0.24 & 4.92 \\
47 & 23.74 & 44.42 & 10.01 & 0.2 & 4.93 \\
48 & 20.86 & 38.99 & 8.81 & 0.15 & 4.92 \\
49 & 19.6 & 37.1 & 8.3 & 0.14 & 4.86 \\
50 & 18.07 & 34.11 & 7.66 & 0.12 & 4.86 \\
\hline
\end{tabular}

Conclusion: Alpha: Pseudocofactor $=2.369$; rate factor $=0.002$.

Beta: Pseudocofactor $=4.394$; rate factor $=0.001$. 


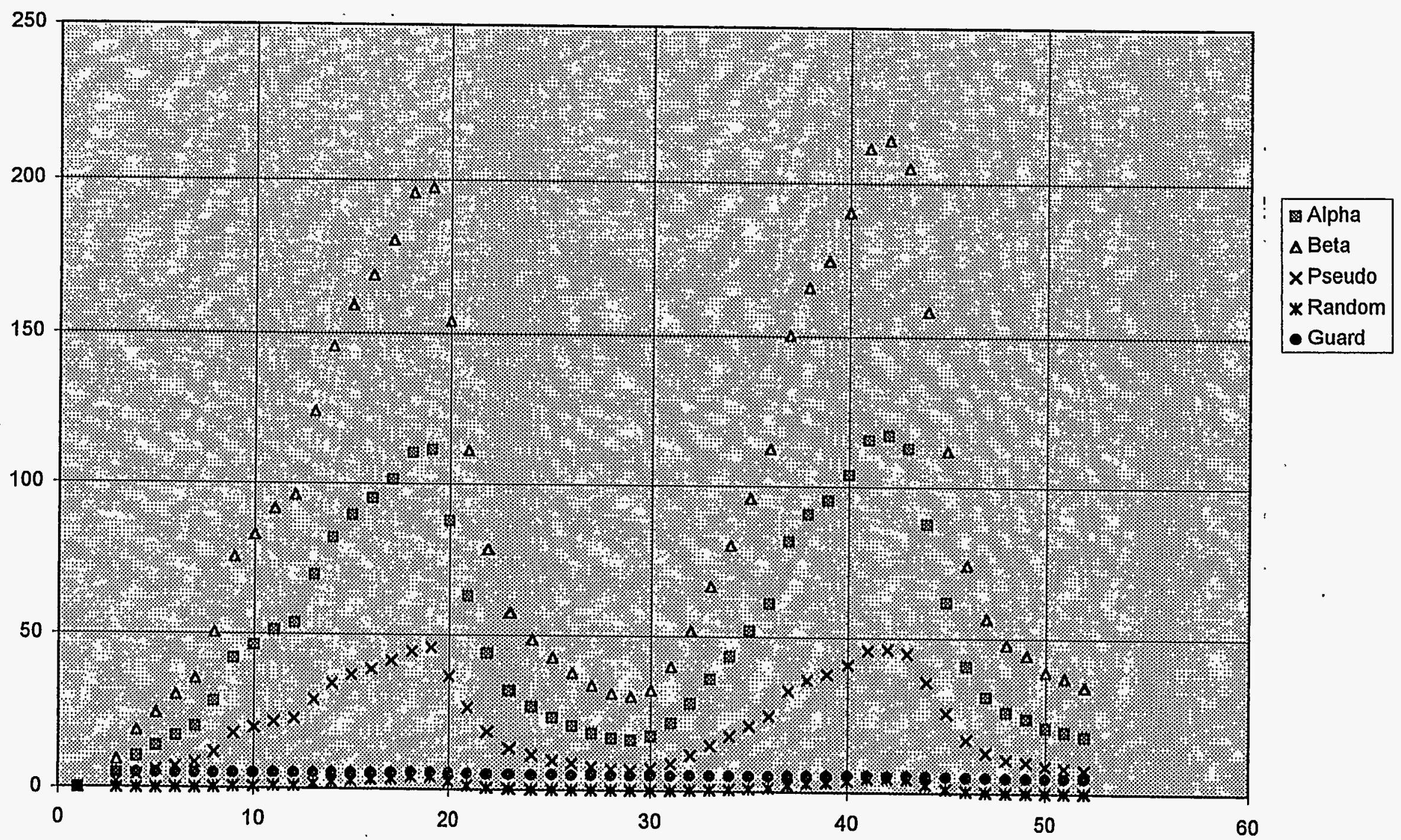

Fig. D.1. Counts per second vs time in hours. 


\section{INTERNAL DISTRIBUTION}

1. J. M. Begovich

2. J. E. Dunn

3-4. L. V. Gibson, Jr.

5. T. E. Myrick

6-11. J. T. Shor
12. Central Research Library

13. Document Reference Center

14-15. ORNL Laboratory Records

16. Y-12 Document Reference Section

\section{EXTERNAL DISTRIBUTION}

17. J. Connolly, Lockheed Martin Idaho Technologies, Idaho National Engineering and Environmental Laboratory, Mail Stop 3875, P. O. Box 1625, Idaho Falls, ID 83415.

18. D. A. Hutchins, U.S. Department of Energy, Oak Ridge Operations, P. O. Box 2001, Oak Ridge, TN 37831.

19. J. O. Moore, U.S. Department of Energy, Oak Ridge Operations, P. O. Box 2001, Oak Ridge, TN 37831 .

20. W. A. Owca, U.S. Department of Energy, Idaho Operations Office, Mail Stop 1235, 785 DOE Place, Idaho Falls, ID 83402.

21. S. J. Priebe, Lockheed Martin Idaho Technologies, Idaho National Engineering and Environmental Laboratory, Mail Stop 3875, P. O. Box 1625, Idaho Falls, ID 83415.

22. S. P. N. Singh, 600 Fernwood Road, Knoxville, TN 37923.

23. S. J. Weeks, Special Technologies Laboratory, 5520 Ekwill Street, Suite 8, Santa Barbara, CA 93111 